\title{
Choreography and Architecture
}

Composing a Framework for Individual Participation

by

Dragana Perusinovic

BAS, Carleton University, 2009

A thesis submitted to

The Faculty of Graduate Studies and Research

In partial fulfillment of the requirements for the degree of:

Master of Architecture

M Arch (Professional)

School of Architecture

Carleton University

Ottawa, Ontario

(C) 2011, Dragana Perusinovic 
Library and Archives

Canada

Published Heritage

Branch

395 Wellington Street

Ottawa ON K1A ON4

Canada
Bibliothèque et

Archives Canada

Direction du

Patrimoine de l'édition

395 , rue Wellington

Ottawa ON K1A ON4

Canada
Your file Votre référence

ISBN: 978-0-494-83191-5

Our file Notre référence

ISBN: $978-0-494-83191-5$
NOTICE:

The author has granted a nonexclusive license allowing Library and Archives Canada to reproduce, publish, archive, preserve, conserve, communicate to the public by telecommunication or on the Internet, loan, distribute and sell theses worldwide, for commercial or noncommercial purposes, in microform, paper, electronic and/or any other formats.

The author retains copyright ownership and moral rights in this thesis. Neither the thesis nor substantial extracts from it may be printed or otherwise reproduced without the author's permission.
AVIS:

L'auteur a accordé une licence non exclusive permettant à la Bibliothèque et Archives Canada de reproduire, publier, archiver, sauvegarder, conserver, transmettre au public par télécommunication ou par l'Internet, prêter, distribuer et vendre des thèses partout dans le monde, à des fins commerciales ou autres, sur support microforme, papier, électronique etou autres formats.

L'auteur conserve la propriété du droit d'auteur et des droits moraux qui protège cette thèse. $\mathrm{Ni}$ la thèse ni des extraits substantiels de celle-ci ne doivent être imprimés ou autrement reproduits sans son autorisation.
In compliance with the Canadian Privacy Act some supporting forms may have been removed from this thesis.

While these forms may be included in the document page count, their removal does not represent any loss of content from the thesis.
Conformément à la loi canadienne sur la protection de la vie privée, quelques formulaires secondaires ont été enlevés de cette thèse.

Bien que ces formulaires aient inclus dans la pagination, il n'y aura aucun contenu manquant. 
Овај рад посвећујем мом деди,

Др. Брани Перушиновћу,

јер он најбоље зна шта ово значи мени,

и ја знам шта ово значи њему. 


\section{Abstract}

As related to architecture, choreography is exhibited as a precise pattern of movement through a sequence of spaces defining the interaction between individual and building. Intended to be reinforced as a habitual pattern of passage through an architectural composition, spatial choreography neutralizes the individual to achieve a collective understanding of architectural intentions. Additionally, the control exhibited by the precise definition of movement through a building is often employed to assert the power and dominance of the program within. As a result, programs of significance adopt an exact pattern of movement that is associated with each subsequent building of the same type. However, the commitment to the same spatial choreography does not account for further programmatic and formal changes acquired over time and reflected by each subsequent building. Therefore, it is necessary to explore means of altering choreography to communicate architectural and programmatic intentions individually rather than collectively. Reflecting on the role of choreography in Modern Dance, can spatial choreography engage the individual in active participation with architecture and the program therein represented? 


\section{Table of Contents}

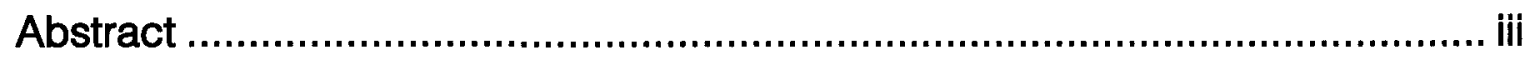

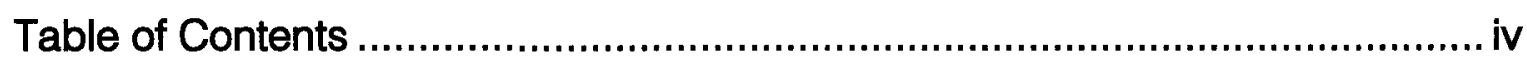

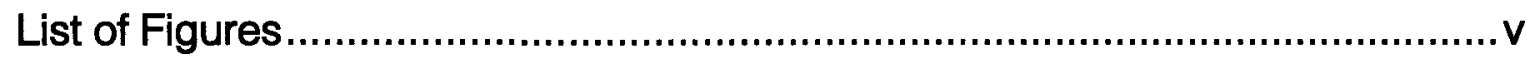

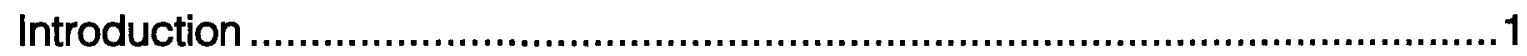

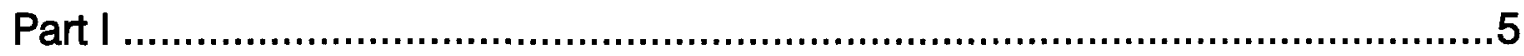

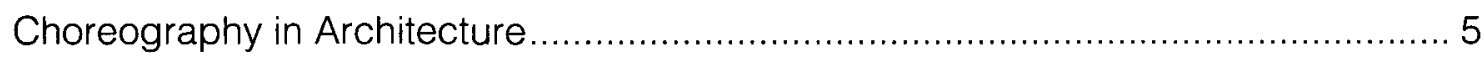

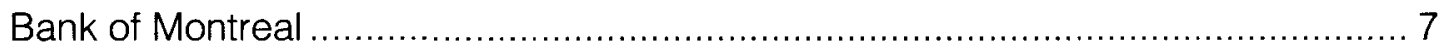

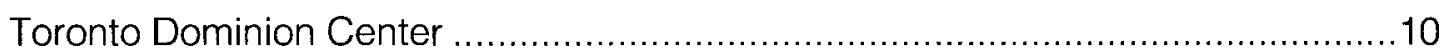

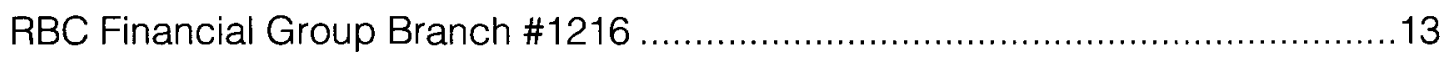

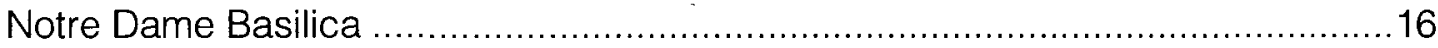

St. Basil's Roman Catholic Church................................................................18

Queen of the Most Holy Rosary Roman Catholic Church ..................................20

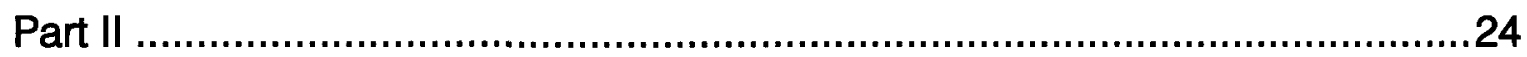

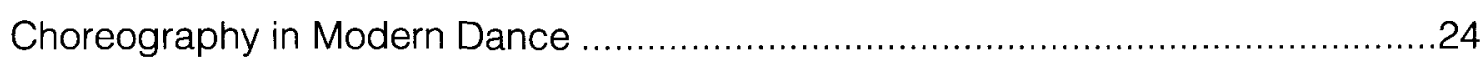

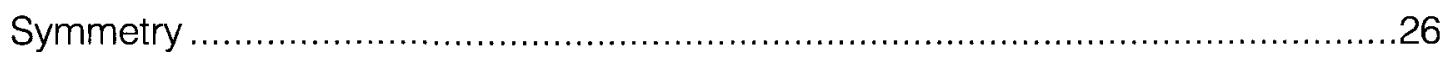

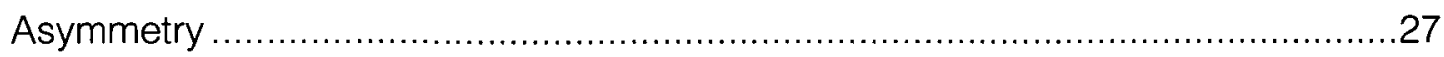

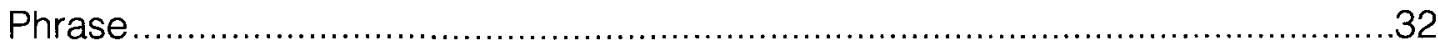

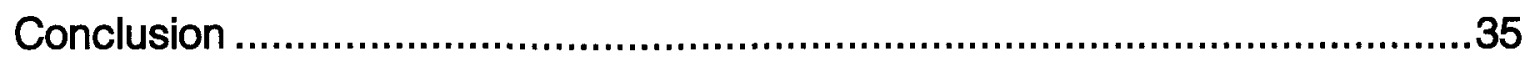

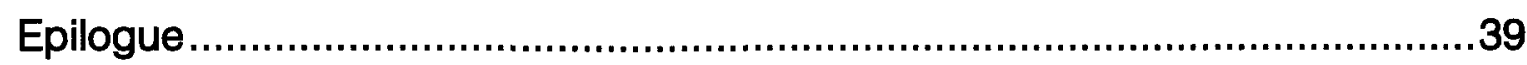

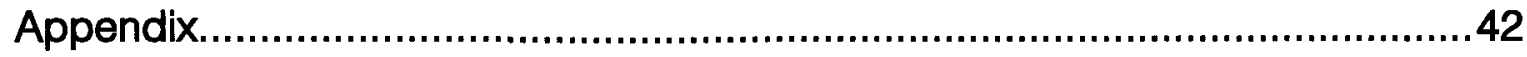

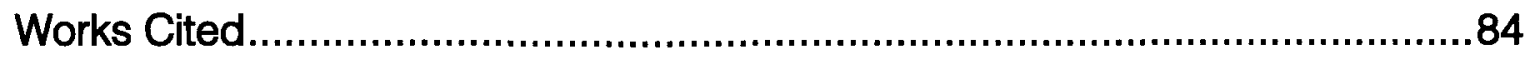




\section{List of Figures}

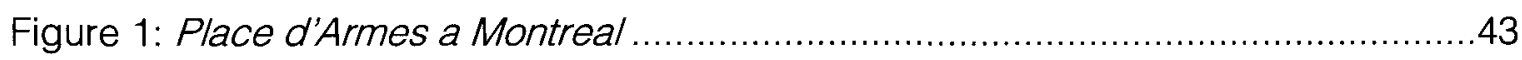

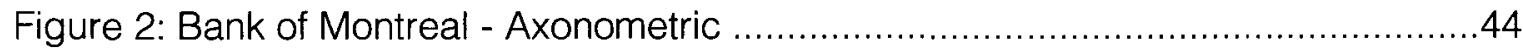

Figure 3: Bank of Montreal - Exploded Axonometric ...................................................

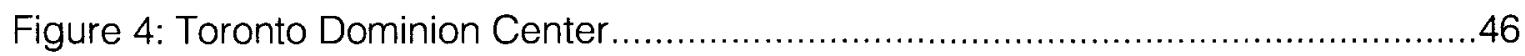

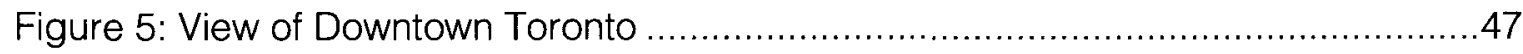

Figure 6: Interior View of the Toronto Dominion Pavilion .............................................48

Figure 7: Toronto Dominion Pavilion - Axonometric ……….......................................49

Figure 8: Toronto Dominion Pavilion - Exploded Axonometric ......................................50

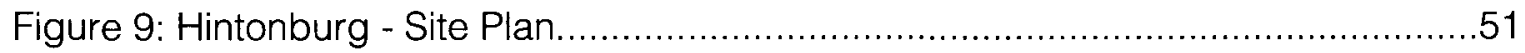

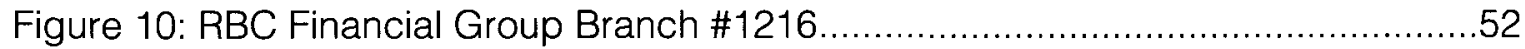

Figure 11: RBC Financial Group Branch \#1216 ....................................................

Figure 12: RBC Financial Group Branch \#1216 - Axonometric ...................................54

Figure 13: RBC Financial Group Branch \#1216 - Exploded Axonometric......................55

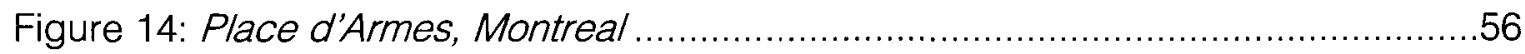

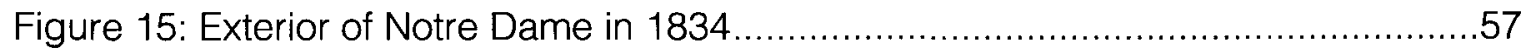

Figure 16: Modular System of the Façade of Notre Dame .........................................58

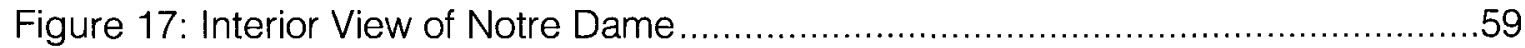

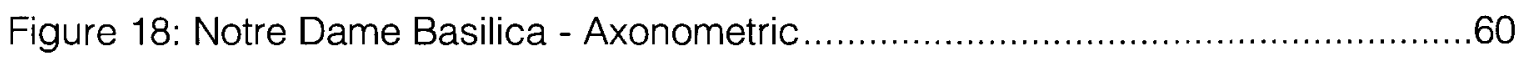

Figure 19: Notre Dame Basilica - Exploded Axonometric ...........................................61

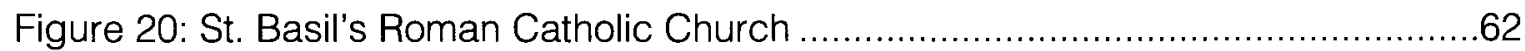

Figure 21: Interior View of St. Basil's Roman Catholic Church .....................................63

Figure 22: Interior View of St. Basil's Roman Catholic Church .....................................64

Figure 23: St. Basil's Roman Catholic Church - Axonometric .......................................65 
Figure 24: St. Basil's Roman Catholic Church - Exploded Axonometric 66

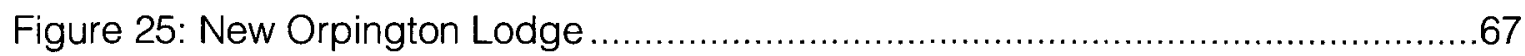

Figure 26: Queen of the Most Holy Rosary Roman Catholic Church ............................68

Figure 27: Queen of the Most Holy Rosary Roman Catholic Church ............................69

Figure 28: Queen of the Most Holy Rosary Roman Catholic Church - Proposed Building 70

Figure 29: Queen of the Most Holy Rosary Roman Catholic Church - Axonometric.......71

Figure 30: Queen of the Most Holy Rosary Roman Catholic Church - Exploded

Axonometric .72

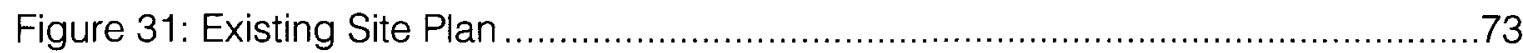

Figure 32: RBC Financial Group Branch \#1216 - Proposed Addition ...........................74

Figure 33: RBC Financial Group Branch \#1216 - Proposed Addition ............................75

Figure 34: Queen of the Most Holy Rosary Roman Catholic Church - Proposed Addition 76

Figure 35: Queen of the Most Holy Rosary Roman Catholic Church - Proposed Addition 77

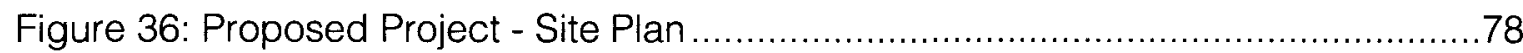

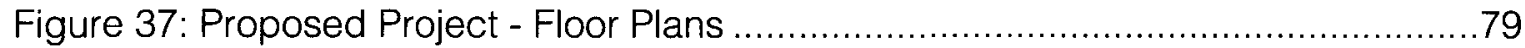

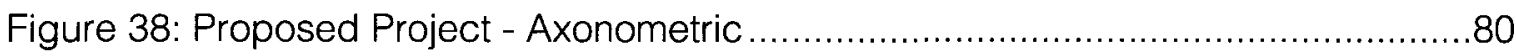

Figure 39: Proposed Project - Exploded Axonometric ..............................................81

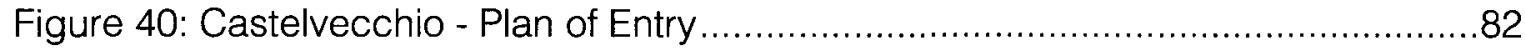

Figure 41: Proposed Project - Exploded Axonometric ..............................................83 


\section{Introduction}

Choreography denotes the act of composing patterns of movement for the human body. With origins in dance, specifically ballet, the term choreography invokes images of highly trained dancers executing sequences of technical patterns. However, composition of movement is not exclusive to dance and is frequently employed in the composition of architectural spaces. Akin to the sequence of dance patterns, a sequence of architectural spaces can determine the movement of the human body. Using order and rhythm, spatial choreography is capable of exhibiting extreme precision by creating controlled navigation of spatial sequences. Extreme control of movement allows the perception of architecture to be delivered and dictated in a precise manner. Additionally, continuous participation in the same spatial choreography forms a habitual pattern. When confined to a single building this habitual pattern affirms the intentions of a specific spatial sequence; however, when applied to a building typology, a habitual pattern is inconsistent with the architectural intentions of each individual building within a typology.

The precise control of movement achieved by spatial choreography is favored by architectural programs that primarily rely on a ritual procession of movement through space. Of particular interest are the Bank and the Church, and their role as programs 
that articulate their power and purpose through the controlled movement of patrons and parishioners. An analysis of the progression of bank and church architecture in Canada illustrates formal change and development consistent with contemporaneous transformations in architecture; however, this development is not reflected in the spatial choreography characteristic of the two programs. Instead, spatial choreography remains unchanged from the first instances of the Bank and the Church in Canada to their present architectural manifestations. As a result, any programmatic changes initiated by the two institutions are not communicated in the constant, habitual pattern of movement characteristic of their architectural typologies. Therefore, spatial choreography becomes incompatible with the program and, subsequently, the architecture it is associated with.

Since their establishment in Canada, the Bank and the Church have undergone significant programmatic transformations reflected in bank and church architecture through appropriate adjustments in formal language. In place of the initial dependence on intimidating scale and grandeur to convey power, the two institutions are actively promoting accessibility through ongoing programmatic and formal changes. However, by remaining unchanged, the habitual pattern of movement achieved by precise spatial choreography is inconsistent with the present architectural representations of the Bank and the Church. Using order and symmetry in the composition of architectural spaces, bank and church architecture continues to achieve rigorous and precise spatial choreography. Therefore, in realizing choreography that is better suited to the present state of the two institutions, it is necessary to reflect on the role of composition in the articulation of spatial choreography. Instead of remaining restrained to a legible but 
monotonous order, can spatial choreography be composed to entice dynamic participation within a cohesive whole?

To answer this question it is necessary to understand the origins of choreography in dance. Transformed from the arrangement of known patterns to a compositional art form through the proliferation of Modern Dance, choreography is used to create a dynamic framework manipulated and interpreted by the moving body of a dancer. Choreographers account for the capabilities of the individual while retaining compositional clarity in the completed work. One such choreographer, Doris Humphrey, articulated her knowledge and theory of choreography, as pertaining to dance, in writing, most notably in The Art of Making Dances. Addressing the design of dance, Humphrey notes the importance of contrasting compositional elements, such as symmetry and asymmetry, to create a dynamic sequence of rises and falls within a choreographed whole. Subsequently, Humphrey outlines the means of composing legible choreography that embraces the individual without sacrificing compositional clarity. Reflecting upon Humphrey's theory of choreography, could the composition of choreography in the art of dance be applied to the composition of spatial choreography in architecture?

Borrowing from Humphrey's theory of choreography in dance, the architectural proposal herein described translates Humphrey's compositional elements of Modern Dance choreography to apply them to the composition of architectural spaces. Using the Bank and the Church as instances of the persistence of precise spatial choreography, this proposal strives to challenge the limitations of choreography in the medium of architecture. Specifically, by altering the spatial composition of two existing buildings, the proposed architecture illustrates the resulting effect on the spatial 
choreography of said buildings. The renovation of existing, symmetrical spatial choreography seeks to introduce asymmetry to create the possibility for dynamic navigation of space through compositional contrast. The compositional changes proposed are intended to reveal and challenge the established choreography of the Bank and the Church, more precisely the RBC Financial Branch \#1216 and the Queen of the Most Holy Rosary Roman Catholic Church in Hintonburg, Ottawa. Can the choreography of the Bank and the Church be reconsidered to better reflect their contemporary roles in Canada? 


\section{Part I}

\section{Choreography in Architecture}

As pertaining to architecture, choreography possesses the ability to precisely define the relationship between the building and the inhabitant. Ideally, choreography presents a guided sequence of spatial experiences intended to become reinforced as a habitual pattern of passage through an architectural composition. Using a meticulous system of rhythm and order, such choreography leads the inhabitant through the determined sequence of passage to deliver a specific understanding of the architectural composition. As a result, spatial understanding is dictated, without deviance, to each individual, forgoing an intuitive act of understanding on the part of the individual in favor of a collective understanding delivered through the specific choreography. Furthermore, by exactly controlling the passage of movement within a building, the use of choreography determines a precise role for the inhabitant within the architectural space. By extension, the significance of the program attributed to said architectural space is asserted through the finite movement imposed upon each individual.

Understandably, highly precise spatial choreography is utilized in the realization of those buildings representing the most prominent programs within a society. The 
ability to designate a role to any individual by determining the interaction between person and building and, consequently, the program, allows a program to elicit patronage simply through interaction with a building. The control associated with the use of finite movement ensures that, upon confronting the building, each individual adopts the predetermined pattern of interaction with both the building and the program therein represented. Most notable among such programs in Canada are the Bank and the Church. The spatial choreography associated with both the Bank and the Church originated in their earliest architectural manifestations. The necessity to attain significance in a new colony required both an assertive and prominent formal language as well as a precise choreography of movement directly related to the understanding of architectural and programmatic ideals. However, while the choreography of the Bank and the Church remained as a habitual pattern of passage, the architectural language associated with both programs was altered to suit the changing perception of significance and stature. As a result, the spatial choreography associated with such buildings no longer directly relates to the program within and, therefore, no longer provides a complete understanding of the architectural composition.

In the case of bank buildings, choreography of movement was initially informed by the necessity of the building to safeguard capital and project an image of assurance and safety to the public. Therefore, the movement of patrons within a bank was limited to the banking hall, severing public access to physical capital while simultaneously celebrating this separation as a necessary sign of security. Fittingly, the formal language employed in the design of the earliest bank buildings in Canada reinforced the necessary image of assurance while readily displaying a sense of wealth associated with the program. Borrowing from British and American precedents, the first 
bank buildings in Canada reflected the affinity for the use of a robust neoclassical language to capture the image of banking in architectural form. Featuring stone construction, imposing colonnades, opulent materials and large banking halls, mass and grandeur conveyed the necessary image of safety while also portraying the potentials of wealth. Combined with the controlled nature of the procession of patrons through the bank building, the aggressive display of imposing stability and significant wealth though materiality asserted the superiority of the banking institution. As a result, the patron of the institution assumed a passive role by adhering to the precisely defined choreography in interacting with the bank building as well as the Bank itself.

Bank of Montreal 119 St. James Street, Montreal, Quebec

In 1817 the Bank of Montreal was established as the first banking institution in Canada. (Money Matters: A Critical Look at Bank Architecture 32) Promptly following its establishment, a suitable bank building was erected in Montreal to serve as the head office of the institution. However, the continuous growth and expansion of the Bank of Montreal necessitated a second building to serve as the head office for the growing company. Chosen as the capital of the newly established United Province of Canada in 1844, new buildings in Montreal were required to represent the prestige associated with a capital city. (Money Matters: A Critical Look at Bank Architecture 36) Additionally, a new head office for the Bank of Montreal needed to express the values and worth associated with the banking institution to current and future patrons. The resultant building [Figure 1], designed by John Wells and constructed between 1845 and 1847, uses clear references to Greco-Roman architecture in articulating the values of 
strength, stability, security and wealth to define both the institution and the city as the capital. (Nolin-Raynauld)

Overlooking Place d'Armes, the front entrance of the Bank of Montreal is covered by a colonnaded portico, indicative of a place of high importance while signaling the beginning of the entry sequence into the building. [Figure 2] The portico, along with the domed roof, creates a distinctive façade, evoking Andrea Palladio, specifically the Villa Rotonda. In fact, the proportions of the building, both interior and exterior, attest to Wells' knowledge and understanding of Palladio and, furthermore, his desire to achieve an ideal order in the design of the building. (Nolin-Raynauld 84) The attention to proportion and order displayed by the exterior façade continues within to create a sequence of spaces characterized by exactitude and navigated as such. Upon entry, an atrium leads to a second colonnade, demarcating the entrance to the banking hall. [Figure 3] The strong verticality of the banking hall, aided by the significant height of the space, is accented by a regular rhythm of pilasters emulating a forward march toward the teller line. The precise passage through the building reveals luxurious materials and rich colours offering to the patron a sense of the wealth associated with the banking institution. The combination of precision and luxury in the composition of the building, as well as the composition of its spatial choreography, evokes the monumentality associated with the most distinguished buildings of the Renaissance, anticipating the same prestige to the seat of banking in the United Province of Canada. The regionally specific relief sculptures on the tympanum along with the use of local building materials reconcile the style of the building with its location in Canada. Along with its central location in the city of Montreal, the architectural 
features of the building serve to contribute to the bank as a place of significance in the newly appointed capital.

As a result of the severe economic downturn of the 1930's, the status of the banking industry, along with the architectural image rooted in neoclassical precedent, was significantly compromised. Following the stock market crash of 1929 and the subsequent Great Depression, the banking industry sought to recover its image and, once again, offer to the public a reassuring portrayal of the banking industry through architecture. Consequently, the banking industry focused on reflecting the innovation and improvements pursued during the post-war period in its architectural manifestations. Beginning shortly after World War II, architectural design of bank buildings in Canada reflected the formal characteristics of the modern movement. Bank buildings of glass and steel were used more frequently to forge a new image for the changing institution. Transparency of the glass façade displayed bank protocol to public view while the modern aesthetic and use of innovative and progressive materials illustrated a commitment to a progressive outlook. Most often structures of great height, the new generation of bank buildings dominated city skylines and occupied central locations. By employing a new architectural language, the banking industry sought to dissociate references to the economic downturn of the past, instead creating a new image that reflects the innovation and improvement associated with future success. (Money Matters: A Critical Look at Bank Architecture 231)

While the new formal language promoted visual engagement with banking protocol through transparency, spatial choreography remained limited to that of prior bank buildings. The habitual pattern of movement determined by the choreography of 
earlier bank buildings remained here unchanged despite the radical formal changes introduced by the adoption of a modern aesthetic. As such, the intentions pursued by the formal language did not correspond with the spatial choreography and, consequently, the spatial choreography was unable to effectively capture the intended interaction with the architecture and, subsequently, the program.

\section{Toronto Dominion Center 55 King Street West, Toronto, Ontario}

One of the first and most significant manifestations of the modern banking skyscraper in Canada is the Toronto Dominion Center designed by Mies van der Rohe and completed with partners John B. Parkin Associates and Bregman \& Hamann. Following the merger of the Bank of Toronto and the Dominion Bank in 1955, Toronto Dominion required a distinctive building to act as the headquarters of the newly established banking institution. In place of a single building, the final design demonstrated a complex, comprised of the Toronto Dominion Bank Tower, a single story banking pavilion, the Royal Trust Tower, a below grade shopping center and below grade public parking all situated on a granite plaza centrally located in the city of Toronto. [Figure 4] The Toronto Dominion complex initiated the development of the area as Toronto's financial district with multiple bank towers appearing in the following years. (Money Matters: A Critical Look at Bank Architecture 231)

The proposed fifty-six storey Toronto Dominion Bank Tower was the tallest building in Toronto to date, and, along with the forty-six storey Royal Trust Tower, was designed to create the presence and stature appropriate for a program of extraordinary importance. (Money Matters: A Critical Look at Bank Architecture 231) Designating such importance to the bank elevated the status of the banking industry and equated it 
with a modern, innovative and progressive outlook. Using modern materials, most notably steel and glass, the image of the bank was propelled forward to reflect the values of a changing society. By using modern architecture to create a new image, the banking industry could once again convey a sense of reassurance to the general public. The ability of the bank building to compete with and exceed the already existing architectural landscape through modern luxury established a sense of aspiration for continuous progress and portrayed it to the public. [Figure 5]

The banking pavilion, housing the Toronto Dominion central branch, is a double height detached building on the corner of King Street West and Bay Street. [Figure 6] The pavilion anchors the complex by defining its relationship with the sidewalk and the street while centering visual focus on public interaction and engagement with banking. The entirely glazed façade, allowing full view of the interior, engages outside participation by exposing the program, treating the interior as performance space and the exterior as the audience space. [Figure 7] The engagement of the general public through the dematerialization of the façade reflects the desire to reassure patrons of the banking industry by offering them an unmitigated view of the occurrences within a bank. However, despite the focus on visual transparency, the spatial choreography strongly resembles that of previous banking institutions. While entry to the pavilion is not limited to a single monumental entrance, accessing the building from any entrance leads to a confrontation with the significant portion of the building dedicated to the teller line. [Figure 8] Perhaps the most significant difference in the choreography of Toronto Dominion, however, is the access created to the remaining portions of the complex, including access to the below grade shopping center as well as access to the neighboring tower. The introduction of additional programmatic elements begins to 
create a distinctive spatial choreography, despite the habitual pattern still evident in the conduct of banking.

One of the most distinguishing factors of the Canadian banking system is the dominance of nationwide branching. Nationwide branching created the opportunity for a fewer number of banks to offer services to an entire nation and in the case of Canada to create several nationally recognized and internationally respected banking institutions. Through competition with each other, banking institutions sought new patrons by offering services in even the most remote locations. (Money Matters: A Critical Look at Bank Architecture 254) As a result of the commitment to accessibility and convenience, the number of branch buildings in Canada increased exponentially while their construction ultimately became synonymous with mass production. However, regardless of its stylistic typology, a bank building continues to retain an assertive presence by engaging the patron in a monumental street front leading to an extravagant banking hall and culminating with guidance from official personnel.

While the interaction between patron and bank building remains largely constant, the act of banking has undergone significant change. Beginning with the Automated Teller Machine (ATM) and continuing with the advent of online banking, the patron has gained previously unprecedented access to banking services. As a result, the attitude towards banking has largely shifted from intimidation to accessibility, a shift that in turn changes the public perception of the banking industry. Unfortunately, the architectural manifestations of the banking industry in Canada continue to reflect the earliest established models of banking and do not support the ongoing changes in the banking industry. 
The close adherence to the architectural understanding of a bank formed at the establishment of the banking industry in Canada has ensured that the roles of both the patron and the bank are retained as they were originally defined. By utilizing the choreography of movement originated in the designs of neoclassical bank buildings the relationship between patron and bank continues to follow the established form. Despite the changes evident in the act of banking, bank buildings remain as monuments to the esteem and power once associated with their presence. As a result, even the most recent architectural representations of the banking institution illustrate a restrictive relationship between patron and bank established through precise and strict choreography of movement.

RBC Financial Group Branch \#1216 1145 Wellington Street West, Ottawa, Ontario As a result of the growing number of branch buildings in Canada, the RBC Financial Group Branch \#1216 was established in the Ottawa neighborhood of Hintonburg. An incorporated village since 1893 and a part of the City of Ottawa since 1907, Hintonburg is located to the west of Ottawa's downtown core and remains a largely residential neighborhood. (History of Hintonburg) The historic center of Hintonburg, the intersection of Parkdale Avenue and Wellington Street West, today marks the intersection of the major avenues of the neighborhood. As the location of the majority of retail and commercial buildings in Hintonburg, Parkdale Avenue and Wellington Street West are also the center of vehicular and pedestrian traffic. The RBC Financial Group Branch \#1216 is strategically located on Wellington Street West among retail and commercial locales. [Figure 9] 
The Branch is located on the corner of Wellington Street West and Mccormick Street, occupying a single storey brick building with a parking lot designated for RBC patrons immediately to the north. The building's irregular shape creates recesses at window locations while also defining the entrance at the corner of the site. [Figure 10] The assertive presence of the building along Wellington Street West, aided by the mass of the brick façade, acts as an extension of the street front delineated by neighboring buildings. However, the brick façade provides a more imposing presence on the street due to the lack of openings denying a clear interaction between building and street. Additionally, the more generous setback of the Queen of the Most Holy Rosary Roman Catholic Church, located immediately to the west, accentuates the stark and severe façade of the bank along Wellington Street West. In contrast, by devoting the north half of the site to on grade parking, the building site remains underused, particularly in comparison to the surrounding area. [Figure 11] Overall, the building is a reflection of ongoing trends in branch construction, focused primarily on the mass production of bank buildings for ease of access to a new client base.

The RBC Financial Group Branch in Hintonburg illustrates the extent of the influence of the precisely defined choreography upon the architectural language of bank buildings. The succession of spaces in this branch building emulates those found in the earliest bank buildings in Canada. The monumental approach is here facilitated by the position of the entrance on the corner of the site as well as the extension of the sidewalk leading to the entrance. [Figure 12] However, like preceding architectural manifestations of the banking industry, access to the interior spaces within the branch building is largely limited to the banking hall. [Figure 13] In contrast to the highly restricted interior, the automated teller machines (ATMs), located in the vestibule, 
provide instant access to many banking transactions prior to entry to the main banking hall. The possibilities offered by the provision of the ATMs draws attention to the prevailing separation between patrons and capital in its physical presence while also prompting a commentary on the physical separation between patrons and the bank building.

Like the bank building, the church building, specifically the Roman Catholic Church, is primarily defined by the composed and choreographed movement of parishioners. However, while choreography defines the nature of the relationship between parishioner and building, its primary purpose resides in the necessity to remove all detractions from the act of worship. The passage of the human body through the space of a Catholic Church is akin to a religious ritual, repeated identically each time to achieve the intended symbolic significance. Furthermore, individualism and division in the postures and actions of the parishioner is strongly opposed in favor of unity in prayer and worship. (Dean 17-8) The choreography of human movement in a religious space is, therefore, the basis for the realization of church buildings. Primary significance is reserved for the act of gathering and assembly in the presence of a higher power, with the physical building serving as a demarcation of the place of gathering. As such, the architectural articulation of a church is significant inasmuch as it allows for the ritual procession of parishioners and the proper articulation of religious services.

The relationship between parishioner and church building, as articulated through the choreography of movement attributed to spaces of worship, is precisely dictated by a complete system of beliefs. Therefore, the execution of the choreography 
illustrates commitment and compliance on the part of the parishioner to the system in question. The act of gathering, the fundamental basis for the establishment of the Church, has become increasingly precise, exactly dictating the nature of movement within the building of worship. The precise choreography of movement does not offer opportunity for individual interpretation or change as it would no longer comply with the purpose which it serves. As such, choreography of movement within spaces of worship, in particular Catholic churches, has remained unchanged and continues to follow the precedents set by the oldest churches in Canada.

Notre Dame Basilica 211 Notre Dame Street West, Montreal, Quebec A feature on Place D'Armes since 1829, Notre Dame Basilica is located on the east side of the square and retains the significance and esteem reserved for the first Catholic Church in Montreal, and Canada, of the scale and stature of a basilica. Construction of the present building, the fourth to act as the Notre Dame Church, was deemed necessary to accommodate the growing Catholic population of Montreal. [Figure 14] Growing competition for superiority within the Catholic community on the part of a new parish church, combined with the scale of the required building, led to the hiring of a New York architect, James O'Donnell, to design an appropriately monumental building. Completed in 1829, Notre Dame, an example of Gothic Revival, was intended as the first major building in the Gothic style in Canada. [Figure 15] Drawing from sources across North America and Europe, O'Donnell's building features two towers on either side of a flat parapet rising to a height of two hundred and eight feet. The astounding height was intended to make the church visible from all of Montreal, with the front façade on view from as far as Sherbrooke Street. However, this view existed only until 
1845, when the west side of Place D'Armes, previously owned by the Church, was sold to the Bank of Montreal and subsequently became the location of their head office.

\section{(Toker 42)}

The monumentality of the exterior façade served to impress the citizens of Montreal, both Catholic and otherwise, while asserting the importance of the Church in the city. The front façade is organized symmetrically and modularly evoking a sense of order and solidarity prior to entry. [Figure 16] The monumentality of the building continues to be evident upon entry where the nave accents the verticality of the space while featuring the sanctuary at its end. [Figure 17] The distance between the columns on either side of the nave varies to create an illusion of greater distance toward the sanctuary giving greater significance to the procession down the center aisle. (Toker

35) The size of the assembly space and the ornamented interior combine for an overwhelming show of significance and splendor to elevate the status of Notre Dame in comparison with all other buildings in Montreal.

While the evident monumentality of the building reflected its desired status in the city, the primary purpose for the building remained constant; to provide adequate space for worship for the growing number of parishioners in Montreal. The spatial choreography reflected this purpose, beginning with the three entrance doors leading parishioners down three aisles through the assembly space. [Figure 18] However, the sanctuary remained the focal point of the interior, commanding the attention of all making the religious service the culminating point of the choreography. [Figure 19] Therefore, despite the impressive scale and form of the building, the spatial choreography remained precise and direct, gathering parishioners and accommodating the act of worship. 
The Second Vatican Council marked a significant change in the relationship between the Church and the changing, modern world. Between 1962 and 1965 the Council explored means of adapting the Catholic faith to modern society by reevaluating, among other aspects of the faith, the liturgy itself. The Council encouraged a higher degree of participation on the part of the parishioner, insisting that "the faithful take part fully aware of what they are doing, actively engaged in the rite, and enriched by its effects." (Sacrosanctum Concilium) The changes in liturgy were reflected in subsequent church buildings where higher participation was actively explored and implemented through new formal strategies. As a result of the conscious means to modernize, church buildings were designed using a modern formal language and organized to increase proximity to and focus on the sanctuary allowing an increasingly direct relationship between the parishioner and the liturgy. However, spatial choreography remained precise, controlled, and exactly reflecting the pattern of movement of prior church buildings. The adherence to previous spatial choreography, therefore, hindered the call to increased participation by imposing the former patterns of movement upon the new form.

\section{St. Basil's Roman Catholic Church 940 Rex Avenue, Ottawa, Ontario}

Completed in 1961, St. Basil's Church was designed and constructed in anticipation of the Second Vatican Council. In accordance with instruction from the Holy See, the Basilian Fathers, who were responsible for the project, requested a contemporary building that would allow greater participation by bringing the congregation closer to the altar. The resulting building, designed by Bemi and Murray Architects, features a 
circular assembly space intended to offer more parishioners closer proximity to the sanctuary. [Figure 20] The assembly space is anchored on the south side by the altar, featured as the focal point of the space with the pews radiating outward to reaffirm this point of focus. [Figure 21] Additionally, the domed roof is a neutral feature, free of structural elements that may deter from the altar as the most significant feature in the building. (Blessing of St. Basil's Church 26)

The main aisle in the assembly space extends from the altar through the narthex to the baptistery as a symbolic gesture signaling the sequence of events in the spiritual life of a person. (Blessing of St. Basil's Church 28) This axis, however, also corresponds with the pattern of movement associated with prior church buildings. [Figure 22] While the form of the building differs significantly from earlier precedents, the spatial choreography of the overall form remains unaltered. [Figure 23] The sequence of entry leads parishioners from the narthex to the nave of the church where the focus is concentrated on the sanctuary and subsequently the altar. [Figure 24] The act of worship is aided by the explicit focus on the sanctuary from all areas of the church and the lack of otherwise unnecessary detractions.

While the formal changes in church buildings appeared to cater to the modernization of Catholicism, the "purpose of liturgical celebration... to bring the participants together in the Trinitarian communion of the Church" (Dean 10) speaks to the irrelevance of form. By this definition, any space that fosters the participation of the congregation and the celebration of liturgy can act as a church. Therefore, the Church is not defined by the building it occupies but by the events occurring within. As a result, parish churches are 
often not of a monumental stature; however, they provide the space necessary for the purpose.

Queen of the Most Holy Rosary Roman Catholic Church 1153 Wellington Street West, Ottawa, Ontario Located to the west of the RBC Financial Group Branch \#1216, The Queen of the Most Holy Rosary Roman Catholic Church in Hintonburg chronicles the development of the neighborhood through its architectural composition. The present building has undergone many transformations, both programmatic and architectural, since its initial construction. The original Victorian home, constructed in the late $19^{\text {th }}$ century, was purchased by the Southwark Catholic Emigration Society to serve as the New Orpington Lodge, a temporary home receiving emigrant children from England. [Figure 25] Due to rapid expansion, the original building was deemed unfit and the living conditions unsatisfactory, leading to the construction of additions on Wellington Street West in 1905 [Figure 26] and on Grant Street in 1921 [Figure 27]. (McEvoy) The extensive renovation of the facility included the adoption of a new name, St. George's Home, in an attempt to establish an entirely new and more favorable image. Upon its closure in 1935, the building was used by the Department of National Defense (Navy) during World War II. Following WWII the building was sold to the Roman Catholic Episcopal Corporation and, after extensive interior renovation, was reopened as the Queen of the Most Holy Rosary Roman Catholic Church. (A History of Queen of the Most Holy Rosary Parish: Ottawa, Ontario)

The exterior of the church building juxtaposes architectural styles that shaped Hintonburg as well as its growth and development at the beginning of the twentieth 
century. While the overall appearance of the building illustrates the haste with which each element was constructed, the composition of the building along with the relationship between the Victorian home and its two additions speak to the intended image portrayed by the architectural language. In particular, the size and placement of the Wellington Street West addition strategically blocked the Victorian home from view to create an improved public façade for the institution housed within. (McEvoy) In accordance with the new image, the newly named St. George's Home commanded respectable attention through the mass of the brick façade while also establishing approachability through the porosity achieved by the dominance of openings.

Having not been constructed as one, the building does not conform to the conventional image and understanding of a church, leading to new architectural proposals upon its purchase by the Roman Catholic Episcopal Corporation. [Figure 28] However, despite the possibility of constructing a new building befitting the existing image of a church, the existing building was deemed appropriate for the purpose of gathering as a congregation and performing religious services. The decision to use the existing structure affirmed the necessity of a church building to foster the precise choreography of a liturgy, above its recognition as a building of formal significance. After the renovation executed at the acquisition of the building by the Roman Catholic Episcopal Corporation in 1946, the interior was made appropriate for gathering, assembly and worship. Since its appropriation for a new purpose, the church building has been embraced by the congregation ensuring its continued life. Despite its unconventional architectural presence [Figure 29], the church is frequented and well loved and continues to be renovated and maintained for its present purpose. (A History of Queen of the Most Holy Rosary Parish: Ottawa, Ontario) 
The renovation of 1946 was particularly extensive and specifically focused on the conversion of the interior spaces of the building. Most significantly, the interior of the Grant Street addition was converted into a double height assembly space while the interior of the Victorian home was made suitable to house the altar and parish offices. [Figure 30] However; the less radical aspects of the renovation are equally significant in creating a space that would support the necessary choreography of the parishioners. Specifically, the windows of the newly established assembly space were relocated at equal intervals to reinforce the necessary sense of ritual through a regular rhythm of interior architectural elements. By employing a marching order of windows and columns, the assembly space encourages the procession through the church and down the center aisle. The overall effect of the renovation created a significant contrast between the interior and exterior of the building, capturing in the interior the necessary elements of a religious space while the exterior remained as a reminder of the complex life of the building.

Since the initial renovation of the Queen of the Most Holy Rosary Roman Catholic Church the interior of the building has been continually renovated to better suit the gathering and movement of parishioners through the space. In the efforts to maximize the ability of the space to support a religious congregation, the original pews, brought to the church in 1946, have since been replaced to allow for side aisles in addition to the center aisle. The provision of side aisle encourages continuous movement through the assembly space allowing a seamless completion of the spatial choreography that leads from the entry, down the aisles and to the pews. The continuous improvements of the building have, thus far, ensured its continued life as a church by improving its ability to support a growing congregation's need to gather for 
the purpose of performing religious services. Those who attend remain fond of the Queen of the Most Holy Rosary Roman Catholic Church, a fondness that may be attributed to the ability of the building to support the needs of a religious choreography above its status as an architectural landmark.

The highly precise and highly limiting choreography of movement characteristic of both bank and church architecture is employed to assert the power of the institution in question by means of controlling the movement of those within. However, the more recent tendency toward accessibility by both institutions does not correspond with the enduring standards of choreography employed in creating their respective architectural manifestations. In the case of the Bank, the accessibility allowed by the increased use of technology to conduct banking is not reflected in the controlled choreography of bank buildings. Similarly, to indicate the integration of the Catholic Church into the modern world initiated by the Second Vatican Council requires a reassessment of the established spatial choreography of church buildings. Therefore, it is necessary for the spatial choreography of both bank and church architecture to become conducive to individual participation in the definition of movement through a building. In exploring a shift in spatial choreography from the controlled to the participative, it is beneficial to reflect upon choreography with respect to the art of dance, specifically Modern Dance. 


\section{Part II}

\section{Choreography in Modern Dance}

Most readily associated with the medium of dance, choreography was recognized as a notable art form during the height of Modern Dance. Doris Humphrey has argued that prior to this period in time choreography was understood as the arranging and assembling of known patterns without great consideration for overall composition. (Humphry 46) However, with Modern Dance highlighting the importance of improvisation to reflect the potential for movement of each individual dancer, particular attention to the composition of dance performance became increasingly necessary. (Humphry 21) As a result, numerous theories of choreography followed, outlining the elements required in composing a dance. Chief among them is Doris Humphrey's The Art of Making Dances.

An extensively trained dancer, Doris Humphrey joined the Denishawn School of Dancing and Related Arts in 1917. Working alongside Ruth St. Denis and Ted Shawn, both widely credited among the creators of Modern Dance, Humphrey began choreographing pieces for the repertoire of the company. She continued to choreograph while developing a distinct style and theory of movement and composition throughout her career which included the founding of the Humphrey-Weidman Dance 
Company along with Charles Weidman, a teaching position at the Julliard School and finally the appointment as artistic director of the Jose Limon Dance Company. (Brown, Mindlin and Woodford 55) One of a few to do so, Humphrey expressed her theories of movement and choreography in writing, with her seminal piece, The Art of Making Dances, published posthumously in 1958.

Prior to addressing her theory of choreography, it is important first to note Humphrey's reflections on dance. Following the departure, in dance, from the formal and technical traditions established over centuries dating back to the Renaissance, Modern Dance introduced profound ideas intended to release the dancer from the confines of strict tradition. During the first half of the twentieth century it was the task of the pioneers of Modern Dance to develop a means of communicating and cultivating this freedom of movement. For Humphrey, this required a practical theory of composition intended as a means of communicating the principles of movement while allowing each dancer to contribute their individual abilities to the final outcome.

(Humphry 18-9) As such, the composition provided a framework within which the body of the dancer may be enticed to interpret the possibility for movement.

As a result of treating composition as a framework for movement, Humphrey's theory of choreography primarily addresses the design of a composition. Careful consideration is given to the role of symmetry and asymmetry within a composition, the former suggesting stability and the latter excitement. (Humphry 50) Humphrey stresses the importance of both to achieve contrast between repose and action or succession and opposition, as the absence of either would result in monotony. Consequently, the contrasts created result in a phrase. A phrase, therefore, contains rises and falls or an exchange between effort and rest. (Humphry 67-8) Reminiscent of the most basic 
human functions, "the heart beats and rests, the lungs fill and subside," (Humphry 67) a phrase creates a recognizable rhythm for a sequence of movement. The recognizable elements of a phrase allow the composition to become accessible to each individual, in turn, creating a physical connection between the individual and the dance.

While Humphrey's theory of choreography is subsequently translated to the stage, it may also be translated to architectural space to address the composition of spatial choreography. The understanding of symmetry, asymmetry and phrase in the composition of a dance can be adapted to the composition of spaces within a building creating a dynamic frame within which the body can move. Applying this understanding to the precise and rigid choreography of the Bank and the Church would result in a shift from the habitual pattern of movement that currently exists toward an increasingly self-aware motion through and navigation of space. Consequently, the new attitude toward spatial choreography would have the ability to correspond with the ongoing changes occurring within the two industries.

\section{Symmetry}

Symmetrical design always suggests stability, repose, a passionless state, the condition before will and desire have begun to operate, or after these have subsided.

Doris Humphrey The Art of Making Dances

The Royal Bank Branch \#1216 and the Queen of the Most Holy Rosary Roman Catholic Church in Hintonburg provide an opportunity for an exploration of a shift in spatial choreography befitting the ongoing changes initiated by both the Bank and the Church. Simultaneously, their proximity creates a possibility to consider choreography at a larger scale, combining programs that primarily rely on precise choreography in navigation of space. [Figure 31] Acting as a reflection of the habitual pattern of 
movement associated with the industries, the existing buildings exhibit symmetrical design with a successional pattern resulting in a ritual navigation of space. (Humphry 58) Altering this ritual requires the introduction of asymmetry and contrast into the spatial composition shifting the choreography from the linear to the three dimensional. By retaining portions of the existing buildings one retains a necessary sense of repose while the introduction of asymmetry through new construction would provide the contrast required to elicit new patterns of movement throughout the space. Therefore, to alter the spatial choreography, the existing buildings will be renovated with additions providing contrast within the composition of the architecture.

\section{Asymmetry}

There lived within the Apollonian man a Dionysus, an unquenchable desire for excitement in breaking all the rules, indulging in the passion for unevenness and freedom from rational balance.

Doris Humphrey The Art of Making Dances

As stated above, asymmetry is a necessary counterpart to symmetry within a composition; however, this counterpart is not present in the spatial choreography of either the Bank or the Church. In the case of the buildings in Hintonburg, spatial choreography is confined to the linear pattern exhibited by their typological predecessors resulting in a monotonous pattern of movement through each building. The renovation of each building must, therefore, focus on the introduction of asymmetry to the spatial choreography, taking great care to retain the contrast created through the relationship between asymmetry and moments of rest and repose. Most significantly, the additions intend to reflect the programmatic changes initiated by the Bank and the Church in efforts to remain appealing to new generations of patrons and parishioners. 
While the entrance to the RBC Financial Group Branch \#1216 is asymmetrical by virtue of being located on the corner of the building, the immediate experience is that of symmetry achieved through the identical rhythm of window openings along the perpendicular walls. After a brief encounter with digital accessibility offered by the ATM in the vestibule, the patron becomes enveloped in the pattern of movement developed by prior bank buildings by first encountering an information desk followed by the teller line. By following the spatial choreography evident in bank buildings of the past, the RBC Financial Group Branch is not representative of the present movement toward digitalization of capital. Today, banking is less concerned with a vault that contains bills, coins and precious metals than a hub for the transmission of data related to financial transactions. To test the architectural implications, and more particularly the spatial choreography of contemporary banking, the addition to the RBC Financial Group Branch consists primarily of a below grade data center while the renovation explores the implications of the digitalization of capital.

The renovation of the existing building addresses the significant programmatic changes within the Branch through the composition of movement across the building and across the site. While the main entrance to the Branch remains the same, asymmetry is introduced into the composition upon entry with a shift in choreography from the linear toward the multidirectional. [Figure 32] Specifically, in place of a direct path toward the teller line the banking hall has been renovated to provide multiple ATM's for common transactions upon entry with bank personnel, offering specialized assistance, located in the northwest portion of the building. With public access possible to both locations, the spatial choreography of the banking hall is now composed with two focal points, one in the immediate foreground and one beyond. By 
creating multiple points of focus within the banking hall, movement is not contained to a single line, but provides multiple paths to engage the individual in the creation of a unique path of movement through the composition. Furthermore, the location of a secondary entrance on the north side of the building creates a possibility for diagonal navigation through the site while providing an additional means of approach and entry to the building.

The renovation of the RBC Financial Brach also addresses the connection between the building and the below grade data center. [Figure 33] The below grade addition is articulated above ground as a single storey tower connecting the existing building to the floor below, while also acting as the primary entrance to the data center. While the data center is not a public programmatic element, it is indicated above grade through a series of level changes to define the north entrance to the Branch and create a public gathering space on site. Additionally, the level changes above grade articulate and define the spaces below while providing access to natural light in staff areas. Combined with the impact of multiple focal points upon entry, the overall composition encourages participation through the introduction of asymmetry into a previously symmetrical spatial choreography. Furthermore, the heightened level of participation in the choreography reflects the accessibility illustrated by the present, digital means of conducting banking.

Like the neighboring Branch building, the Queen of the Most Holy Rosary Roman Catholic Church displays great resolve in embracing symmetrical order in its design. Evident upon entry, the symmetry exhibited by the front façade of the Church is continued inside the building, most notably in the assembly space. Here, the equal rhythm established by the exchange of columns and windows invites forward motion 
through the space. The focal point, the sanctuary, is, appropriately, located at the culmination of the center aisle completing the strong linearity of the spatial choreography. Additionally, the altar is centrally situated in the sanctuary as a continuation of the prevailing symmetrical design of the interior of the Church. The prevalent symmetry of the Queen of the Most Holy Rosary Roman Catholic Church ensures that spatial choreography remain precise, exactly emulating prior Catholic churches. However, the adherence to the existing spatial choreography encourages linear movement, denying the possibility for individual navigation of space. Altering the existing spatial choreography requires an introduction of asymmetry into the architectural composition.

To introduce asymmetry to the spatial choreography of the Queen of the Most Holy Rosary Roman Catholic Church it is necessary to disrupt the rigorous symmetry exhibited in the assembly space leading to the sanctuary. To begin, the marching rhythm created by the succession of windows and columns is altered by the introduction of full height glazing between columns on the east side. [Figure 34] The glazing acts a means of access to an addition to the east of the existing building; however, it also breaks the balance and challenges the symmetry of the assembly space. The symmetry of the existing building remains intact in the first two bays of the assembly space, while asymmetry is introduced in the following three bays by opening the space and expanding it through the glazing toward the addition. The existing rhythm remains evident in the succession of columns throughout the space; however, the introduction of the glazing feature shifts the pattern of motion from the strictly linear toward the multidirectional. 
The asymmetry achieved through the use of glazing within the existing building reaches a climactic point of contrast in the addition. [Figure 35] The addition to the east of the existing building acts as an expansion of the assembly space of the Church. Accessible from within as well as outside of the building, the addition is an exterior space intended for larger gatherings, special services and informal exterior gatherings by the congregation. By remaining an exterior space, the addition projects the existing assembly space outwards, blurring the threshold between interior and exterior and immaterializing any sense of linearity and symmetry within the choreography of the building. Furthermore, the informal and public access to the addition alters the existing entrance sequence allowing access at multiple locations when both the interior and exterior assembly spaces are in use. The altered entrance sequence allows for multiple perspectives of the building through an asymmetrical approach to the entry. The contrast between the existing and the addition is affirmed through the sharp contrast in materiality; however, the rhythm of successive columns present in the existing is also used in the addition, reintegrating a sense of symmetry to highlight the contrast achieved through the introduction of asymmetrical movement.

Transforming the linear pattern of motion within the Church requires particular consideration be given to the design of the sanctuary. Despite the changes in choreography, the sanctuary remains a significant location in the Church due to its role in the liturgy; therefore, it must ultimately be the focus of the expanded assembly space. To retain the required focus, the location of the altar within the sanctuary must be addressed. Specifically, by locating the altar asymmetrically to the west, the assembly spaces, both interior and exterior, share a diagonal line of sight culminating at the altar. While altering the spatial choreography of the Church allows a variation of 
movement to encourage individual participation in the choreography, the ability of the building to support religious services is retained by the ultimate focus of the space on the altar and the sanctuary.

The introduction of asymmetry into an otherwise symmetrical space, such as the RBC Financial Group Branch \#1216 and the Queen of the Most Holy Rosary Roman Catholic Church in Hintonburg, alters the existing linear spatial choreography to allow dynamic movement through and navigation of space. By forgoing a single, precise, controlled pattern of movement, an architectural composition invites participation in and interpretation of spatial choreography. The initiative necessary to navigate such a space results in an active interaction with architecture. In the case of programs that are primarily defined by the movement of people, such as the Bank and the Church, the introduction of asymmetry into the composition of architectural space invites individual participation in the program by means of the architecture. Therefore, the spatial choreography can begin to reflect the accessibility otherwise pursued by the two institutions. Additionally, by achieving a balance between asymmetry and symmetry within a spatial composition, the essential clarity of each program remains legible in the choreography of each building.

\section{Phrase}

... people are happier when a maze of sensation can be sorted out into some kind of order... Without this, it quite easily becomes a labyrinth of movement, distracting and puzzling.

Doris Humphrey The Art of Making Dances

The spatial choreography of the renovated buildings, both the Branch and the Church, is intended as a single phrase. [Figure 36] The combination of symmetry and asymmetry creates rises and falls within the composition while participation in the given 
program through the choreography ensures a beginning and an end. (Humphry 68) Between the beginning and the end of each phrase, however, there is a high point giving the overall choreography the intended dynamic composition. [Figure 37] In the case of the Branch, this high point occurs near the middle of the phrase, more precisely upon confrontation with multiple points of focus within the renovated banking hall. In the case of the Church, the high point occurs at the end of the phrase. Here, the altered choreography through the church culminates with the diagonal focus on the sanctuary and, subsequently, the service conducted. The familiar rise and fall of each phrase allows the composition of the choreography to remain legible and comprehensible despite the intricate relationship between elements of symmetry and elements of asymmetry.

As a result of the adjacency of the RBC Financial Group Branch \#1216 to the Queen of the Most Holy Rosary Roman Catholic Church, the spatial choreography of the site must also be addressed ensuring a comprehensive collective composition. [Figure 38] To begin, due to their proximity, the exterior spaces of the two buildings complement each other in support of both programs. [Figure 39] Specifically, the gathering space to the north of the Branch is created with the possibility of supporting outdoor gatherings of the Queen of the Most Holy Rosary Roman Catholic Church congregation. As an indication of the possible programmatic extension, the two exterior spaces share similarities to relate each to the other. For example, the column spacing evident in both the existing church and the addition is extended to the adjacent gathering space creating a compositional continuation from one space to the other. However, the two spaces remain different in materiality and form distinguishing them as parts of separate buildings. The composition of the overall site, therefore, 
allows each building to function separately while also allowing the whole site to function collectively as a single phrase. Beginning with the high point inside the church, the phrase is resolved with the extension of the gathering eastward across the site.

Creating recognition within a composition, a phrase resolves the intricate relationship between symmetry and asymmetry. However, despite its legibility, a phrase retains the dynamic movement of the choreography by including variations, rises and falls throughout the composition. In the case of the Branch and the Church in Hintonburg, phrasing defines both the composition of the individual buildings as well as their relationship on the site. Through the use of the phrase, the dynamic choreography achieved by the composition and juxtaposition of symmetry and asymmetry is communicated in a legible and accessible manner. As a result, the individual assumes an active role in the definition of spatial choreography with the aid of a recognizable phrase of movement. 


\section{Conclusion}

Through their architectural typologies, the Bank and the Church demonstrate a dependence on the defined movement of patrons and parishioners to achieve the intentions of their programs. An analysis of bank and church architecture in Canada illustrates the commitment of both building typologies to precise spatial choreography. Defined by the first instances of the Bank and the Church in Canada, the spatial choreography representative of each building typology has since remained unchanged. Additionally, the recurrence of the same spatial choreography in each subsequent bank building, or each subsequent church building, results in a discrepancy between a changing formal language and an unchanged pattern of movement. Therefore, any formal or programmatic changes undertaken by the two industries since their establishment in Canada are not communicated through the participation in the program by means of the existing spatial choreography. In particular, the ongoing commitment to accessibility by both the Bank and the Church is not reflected by the precisely defined choreography of their architectural manifestations.

The development of the bank building in Canada chronicles the development of the banking industry in the country. Beginning with monumental neoclassicism used to 
communicate reassurance in the stability of the banking industry at its outset in Canada and continuing with the modern use of steel and glass to recapture significance and status following the Great Depression, the formal qualities of bank buildings reflected the continued development of the banking industry. However, the spatial choreography of bank buildings did not undergo changes to reflect the new formal language. Instead, the pattern of movement established by the earliest neoclassical banks in Canada remains present in even the most recently constructed bank buildings. As the banking industry continues to develop, adopting technological advancements into banking practices, the bank building continues to exhibit the precise and contained spatial choreography associated with the neoclassical model.

Similarly, the Catholic Church has embraced the precise spatial choreography established by the earliest Catholic churches in Canada. Related to the precise execution of religious services, the ritual procession through a church remains exact regardless of the formal appearance of the building. While the reconciliation of the Catholic Church and the modern world, initiated by the Second Vatican Council, resulted in significant formal changes, spatial choreography remained unaltered. Therefore, the desire of the Catholic Church to appeal to new generations of parishioners failed to be communicated in the sequence of movement through a church building.

The precision characteristic of the spatial choreographies of bank and church architecture has resulted in a discrepancy between the programmatic intentions of the two building typologies and their execution through the movement of the patron and the parishioner. The ongoing pursuit of accessibility and participation by both industries illustrates a necessity for an alternate approach to spatial choreography. Changing the 
existing habitual pattern of movement that comprises the choreography of bank and church buildings requires a comprehensive understanding of the composition of choreography. Such an understanding may be derived by analyzing the development of choreography in Modern Dance and applying them to the choreography of architectural space.

The role of choreography in Modern Dance illustrates a possibility for choreography to allow individual interpretation within a composed whole. Understood through the lens of Modern Dance, choreography is a composed framework for the moving body. Choreography is, therefore, composed as a dynamic phrase of rises and falls to be interpreted by the dancer. Using the methods of composition featured in Modern Dance, specifically as outlined by Doris Humphrey, the sequence of movement through architectural space can become more dynamic. Applying Humphrey's theory of composition and choreography to a work of architecture offers the dynamics of dancing to the navigation of architectural space. In so doing, spatial composition no longer acts as a means of precisely defining choreography but as an invitation for movement. Therefore, the proposed renovations of the RBC Financial Group Branch \#1216 and the Queen of the Most Holy Rosary Roman Catholic Church reflect an attempt to introduce dynamic motion into a previously precise and controlled spatial choreography.

Using the compositional contrast between symmetry and asymmetry outlined by Humphrey in The Art of Making Dances, the proposed renovations of the Branch and the Church alter the previously linear sequence of movement to offer the possibility for movement in multiple directions. While encouraging dynamic navigation of the architectural composition, this change in spatial choreography supports and invites 
participation on the part of the individual in the act of navigating each building. By creating the possibility for individual involvement in the definition of the path through a building, the building becomes more accessible to the individual. As related to the Branch and the Church, this accessibility represents the ongoing changes in both industries more readily than the present spatial choreography, one which remains unchanged from the introduction of the two buildings in Canada. 


\section{Epilogue}

Following the examination of the role of spatial choreography in bank and church architecture through the proposal for the renovation of the Queen of the Most Holy Rosary Roman Catholic Church and the RBC Financial Group Branch \#1216 it is of value to reflect on the potential for the above to inform further architectural investigations. Specifically, understanding the impact of spatial choreography on the relationship between architecture and individual can influence the composition of spaces within a building. Similarly, recognizing patterns of movement through an architectural composition offers the possibility for a better understanding of the interaction between architecture and individual. Therefore, developing a method for graphically examining spatial choreography in buildings would allow the research herein undertaken to be applicable to future explorations of choreography in architecture.

Throughout the preceding thesis, the research as well as the architectural proposal that followed are supported and complemented by axonometric drawings of buildings discussed. The use of the axonometric drawing, particularly the exploded axonometric drawing, reflects a desire to understand architecture as a sequence of 
compositional elements influencing the pattern of movement of the people within. While the exploded axonometric communicates the architectural composition of a building, the specific movement of people within is not clearly discernable. As a result, the navigation of space cannot be closely examined using only the axonometric drawing. Therefore, further investigation of spatial choreography requires additional precision in the representation of the movement initiated by the composition of the building.

To represent movement through space in the axonometric drawings of the proposed renovation of the Queen of the Most Holy Rosary Roman Catholic Church and the RBC Financial Group Branch \#1216 requires an additional layer of information. This additional layer becomes more evident when reflecting on the drawings of Castelvecchio by Carlo Scarpa. [Figure 40] Scarpa's drawings display particular sensitivity toward the navigation of architecture. Specifically, plans often feature markings outlining passage from one space to the next, through the building. Borrowing Scarpa's manner of recording movement through space provides additional clarity to the drawings of the proposed renovations of the buildings in Hintonburg. [Figure 41] In addition to the compositional clarity achieved through the use of the axonometric drawing, the additional layer of information provided by the outline of passage through the building achieves the precision necessary to examine spatial choreography closely using drawings.

The clarity attained by explicitly addressing the movement of people through a building in drawing allows the drawing to become a useful tool for examining the role of choreography in architecture. While communicating the relationship between the building and the individual within, the drawing can also be used to analyze and evaluate this relationship. By creating a means of exploring, investigating and 
understanding the effects of spatial choreography in architecture the intentions of this thesis can be ascribed to future architectural proposals 
Appendix 


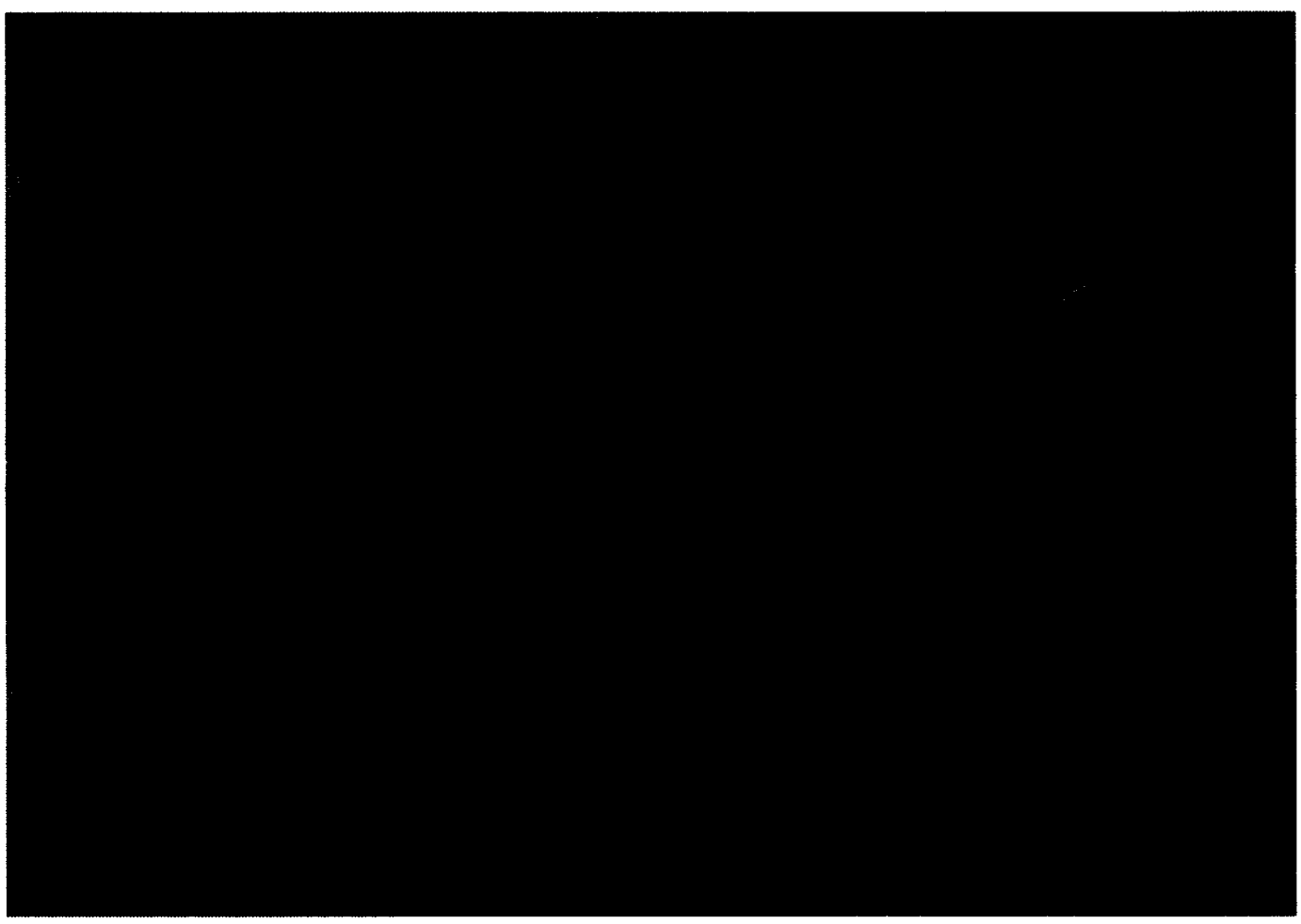

Figure 1: Place d'Armes a Montreal

Cornelius Krieghoff

1848

Ink on paper

McCord Museum of Canadian History 

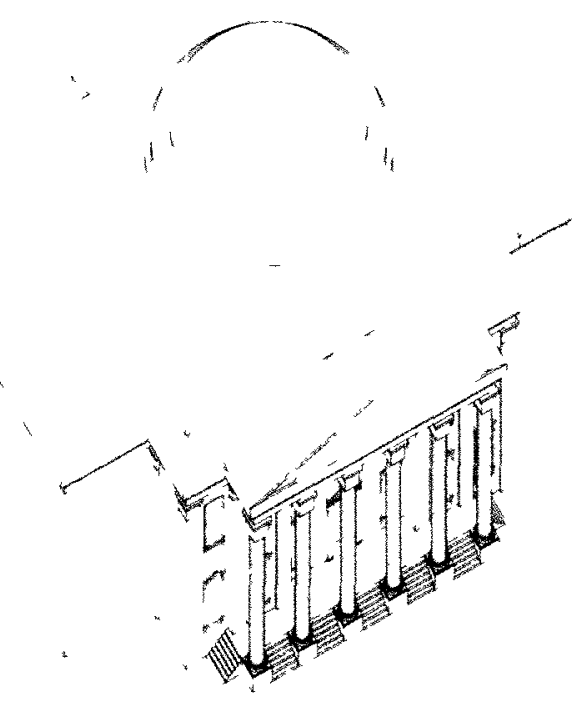

Figure 2: Bank of Montreal - Axonometric 


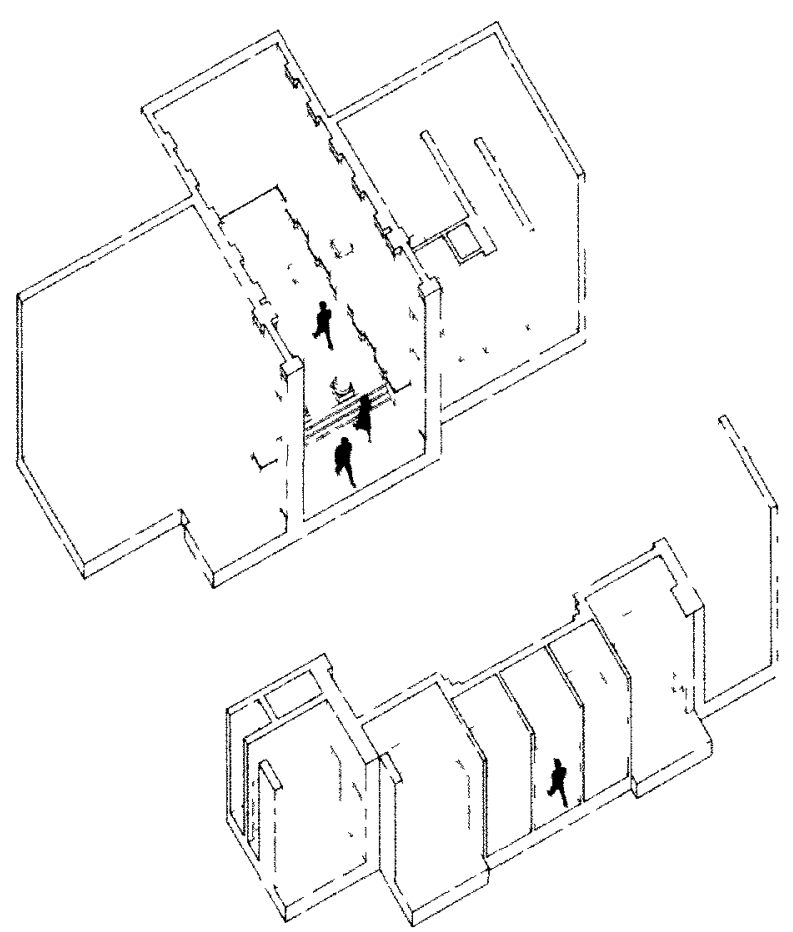

4

Figure 3: Bank of Montreal - Exploded Axonometric 


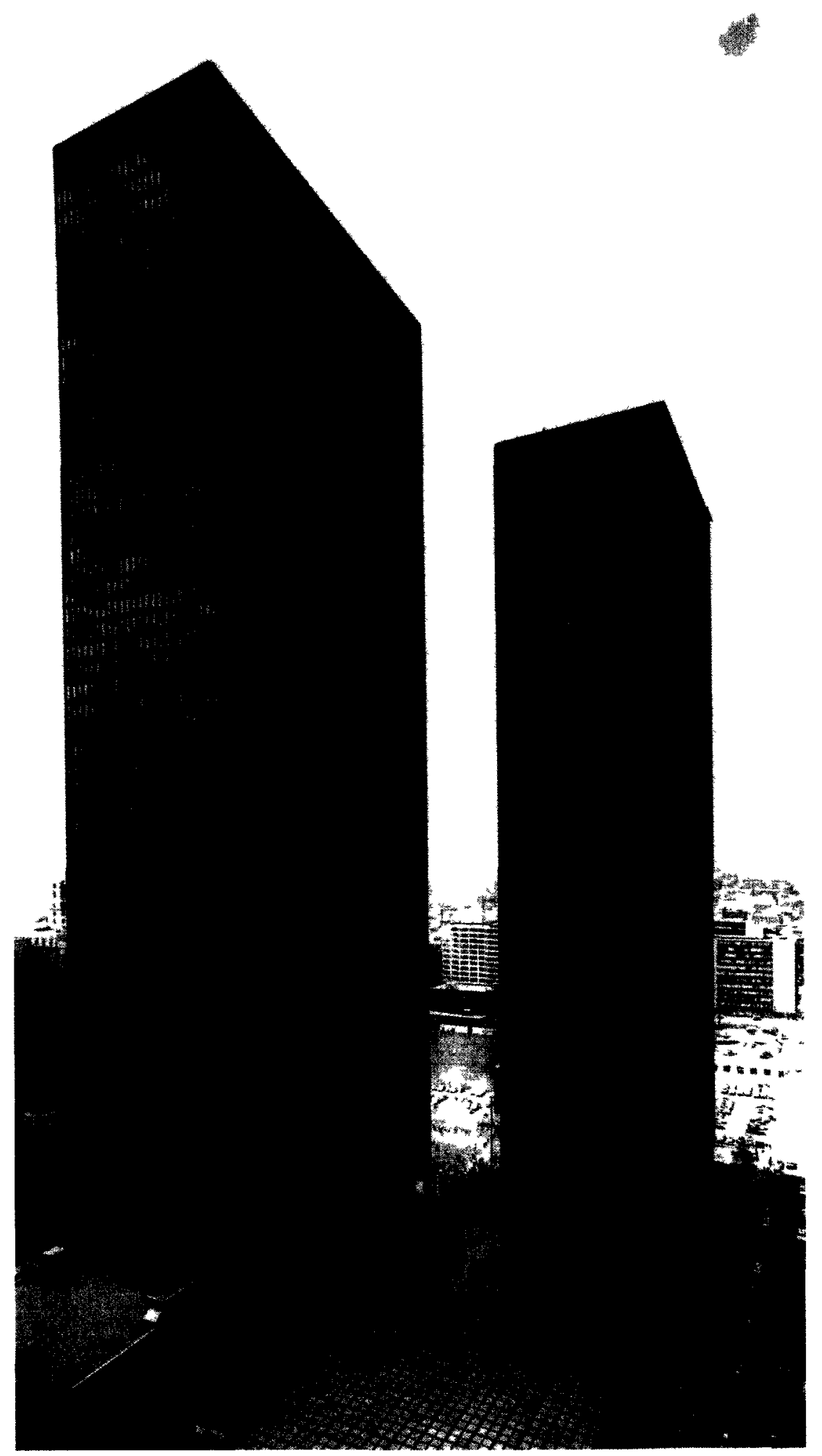

Figure 4: Toronto Dominion Center

The Mies van der Rohe Archive

Pg 259 


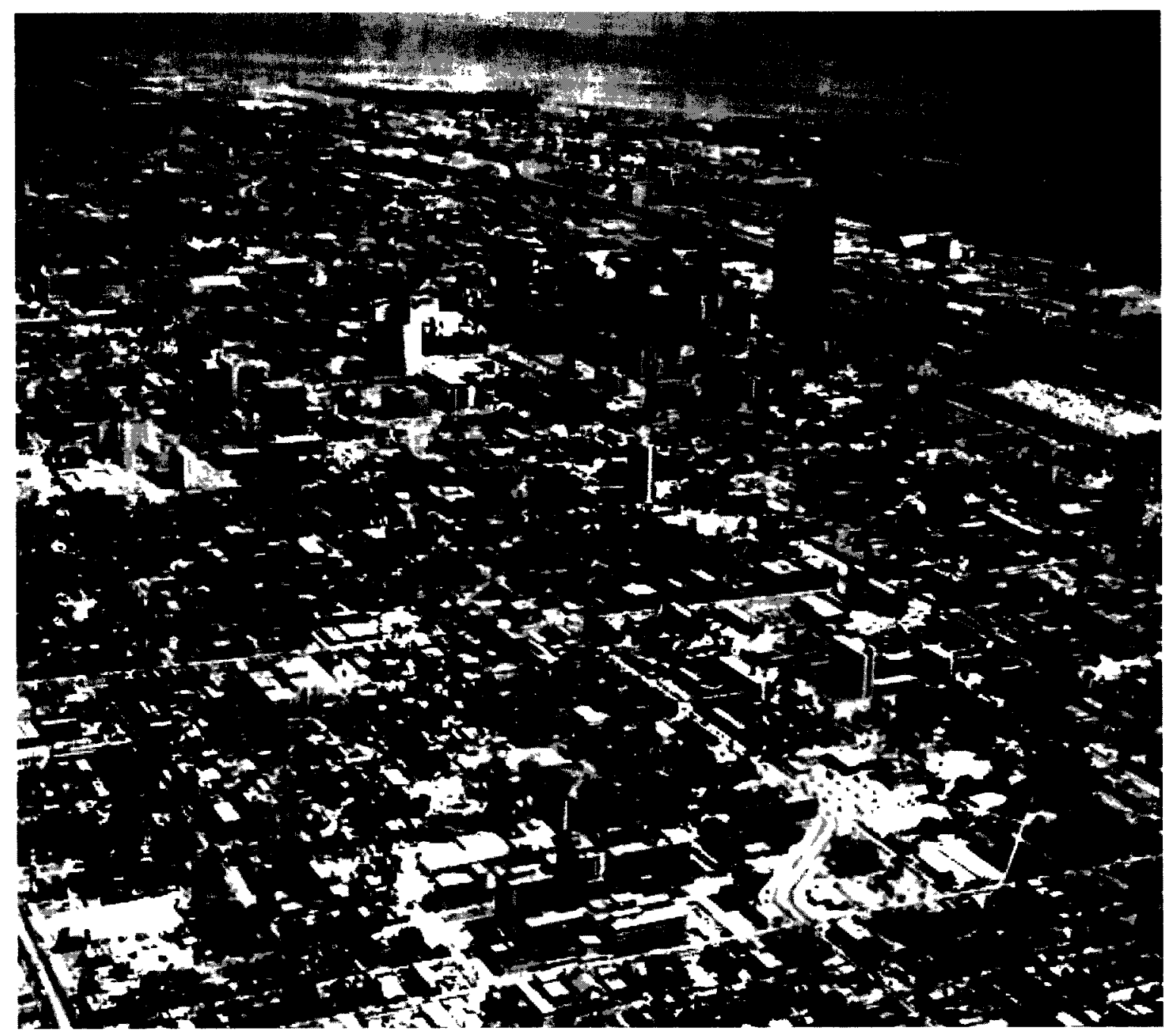

Figure 5: View of Downtown Toronto

Toronto Dominion Center circa 1970

"Toronto Without the Tower" 


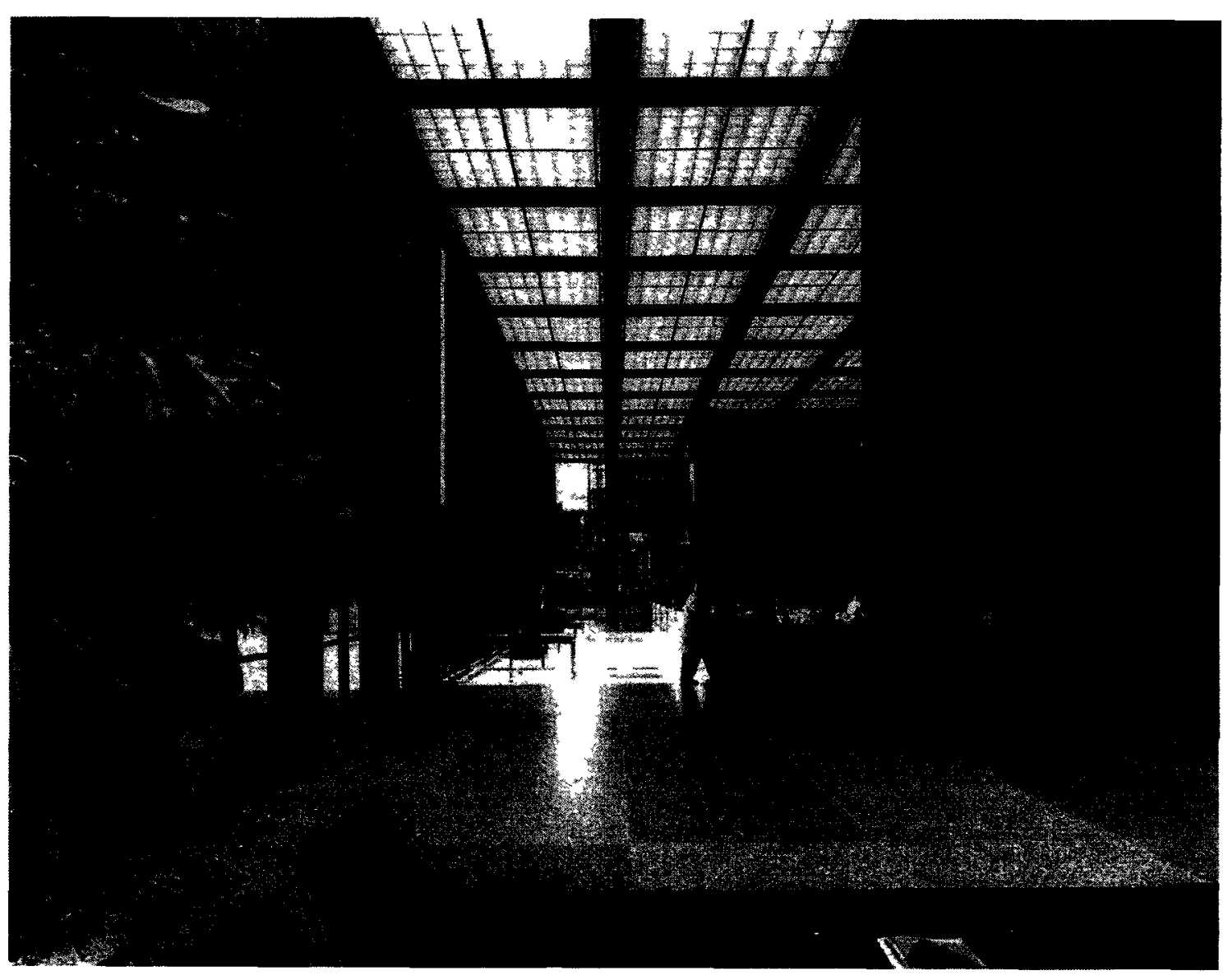

Figure 6: Interior View of the Toronto Dominion Pavilion

The Mies van der Rohe Archive

$\mathrm{Pg} 258$ 


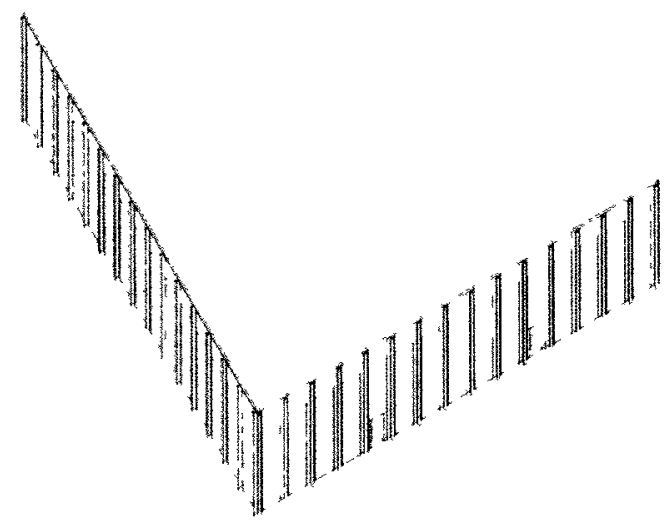

Figure 7: Toronto Dominion Pavilion - Axonometric 


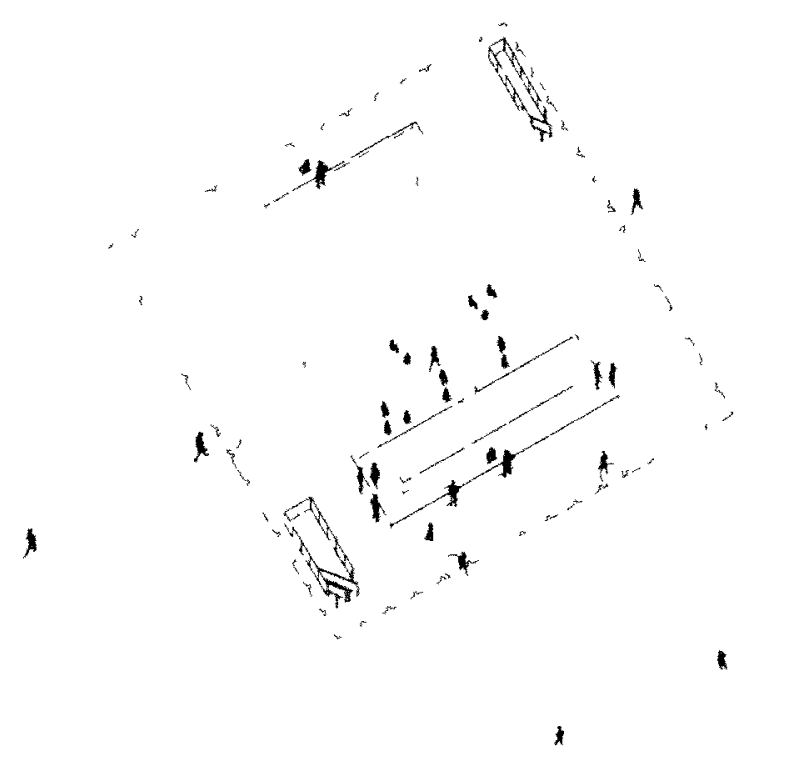

Figure 8: Toronto Dominion Pavilion - Exploded Axonometric 


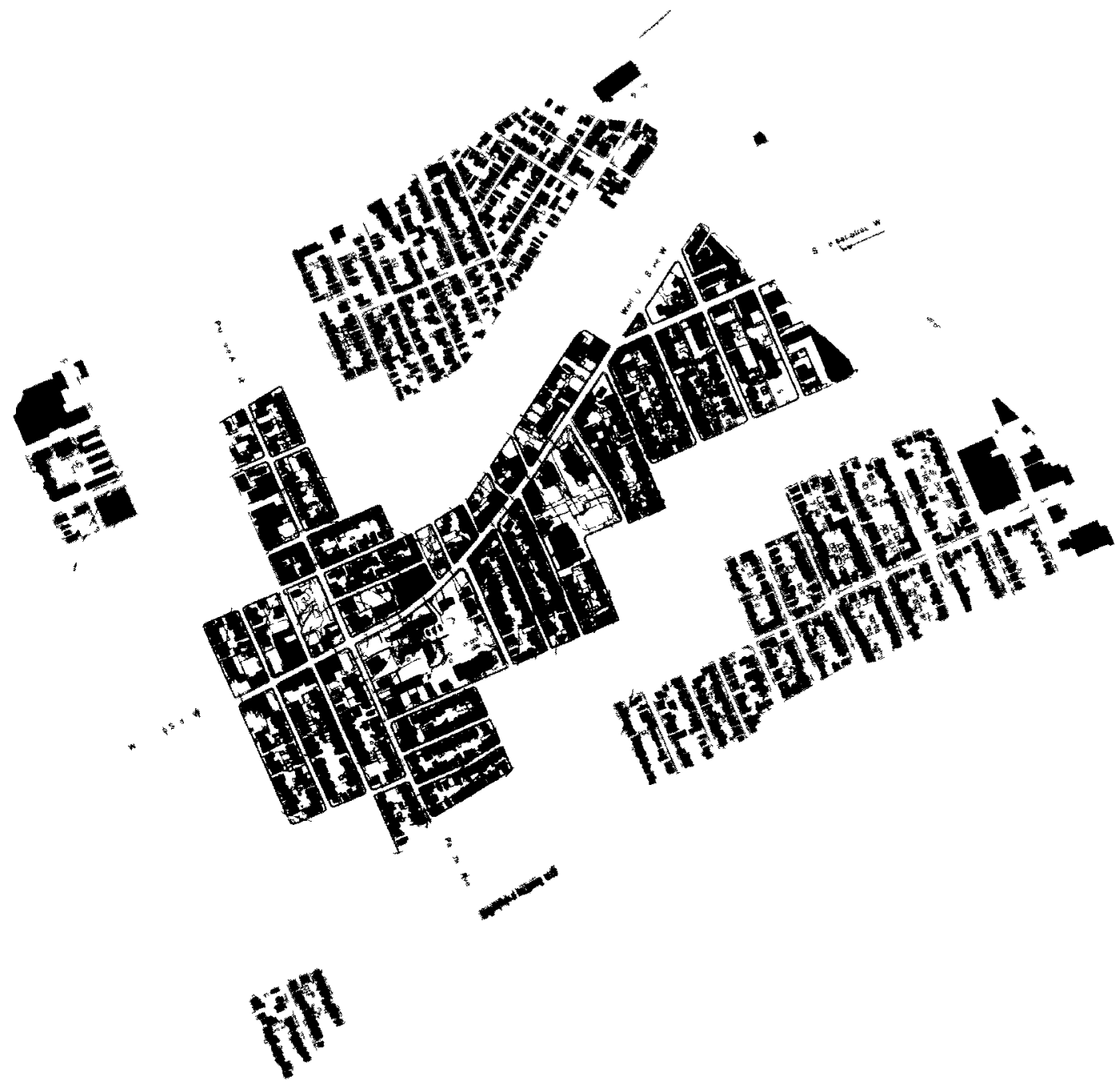

Figure 9: Hintonburg - Site Plan 


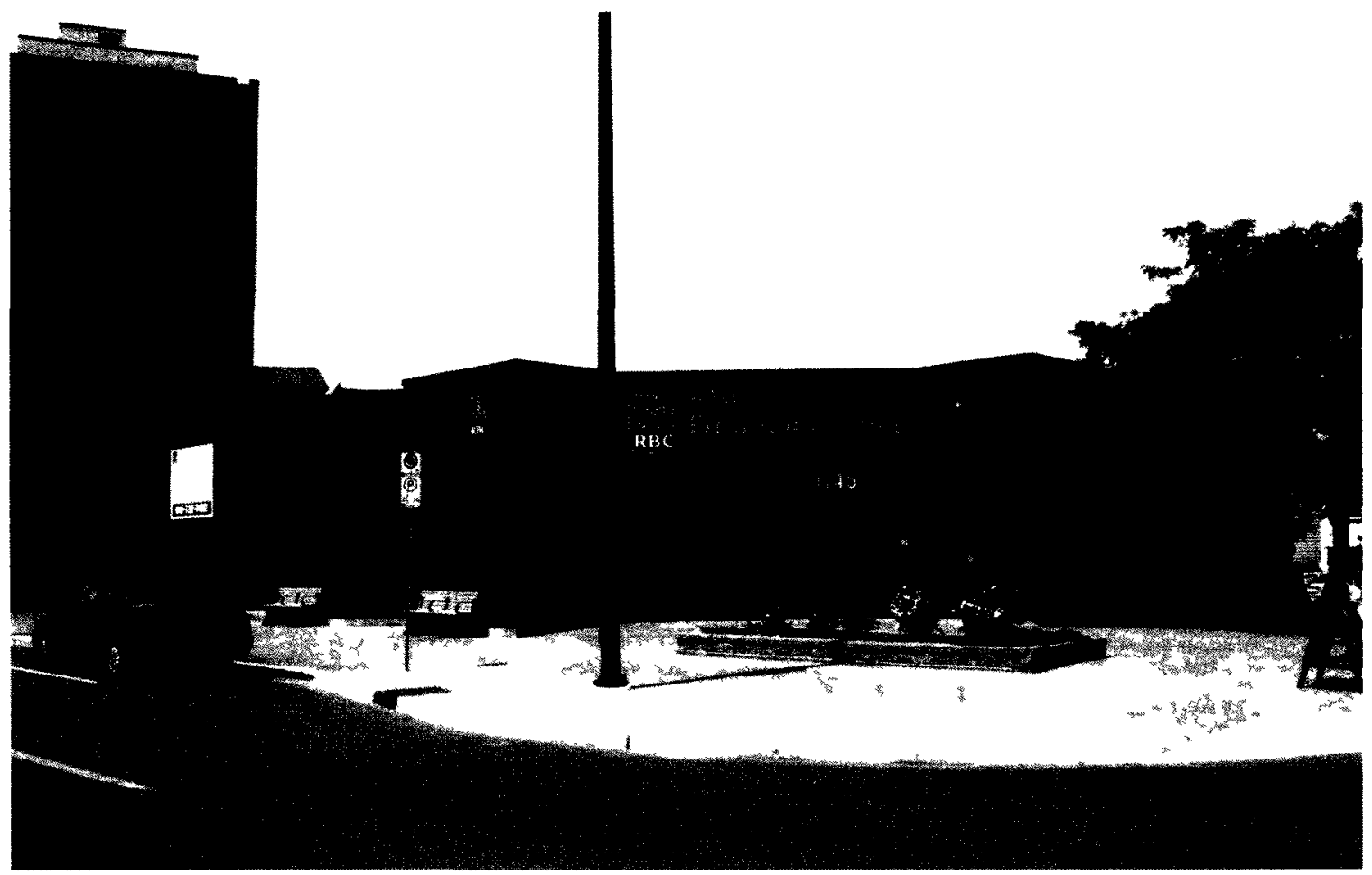

Figure 10: RBC Financial Group Branch \#1216

View from Wellington Street West 


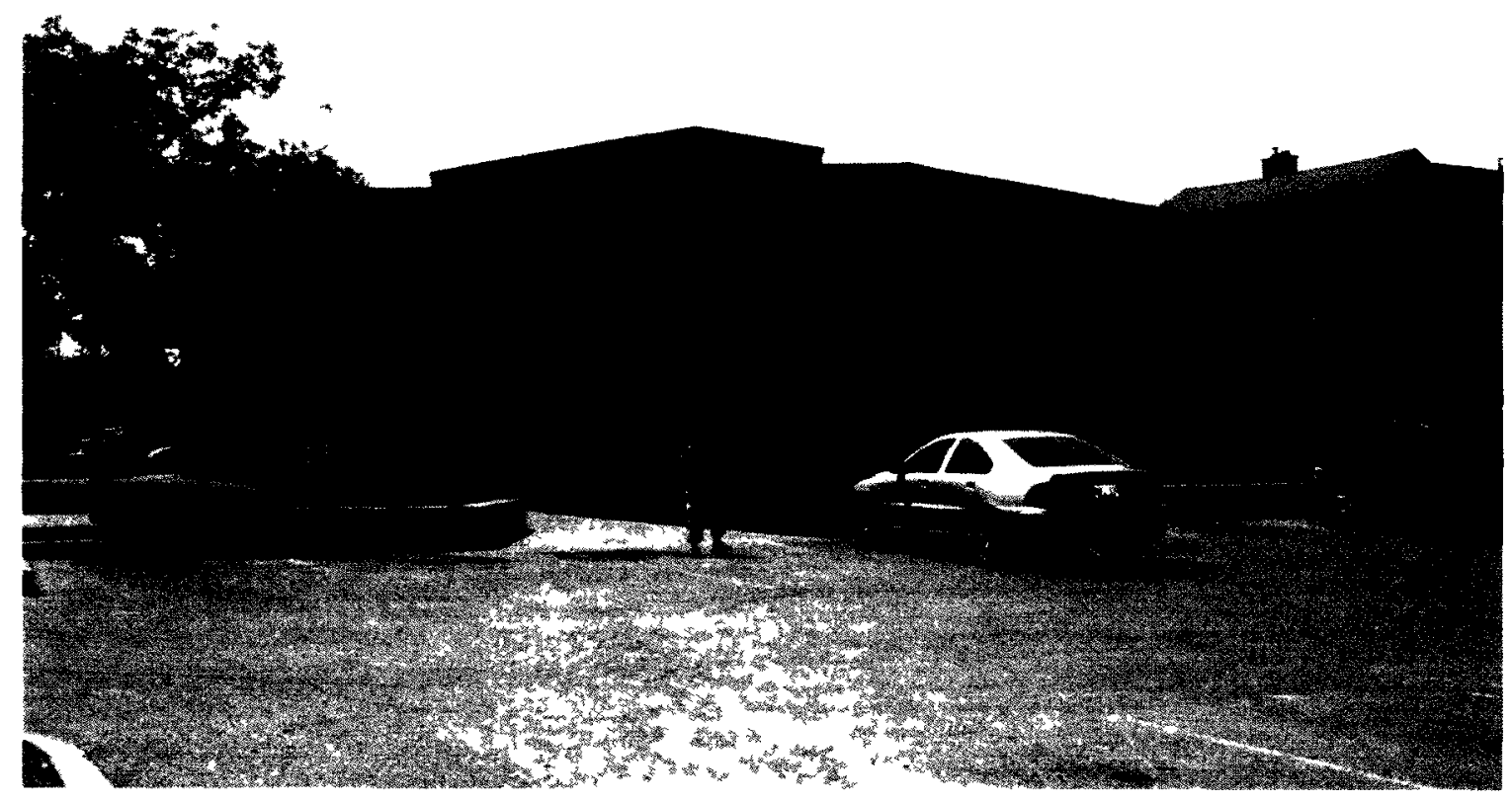

Figure 11: RBC Financial Group Branch \#1216

View from Grant Street 


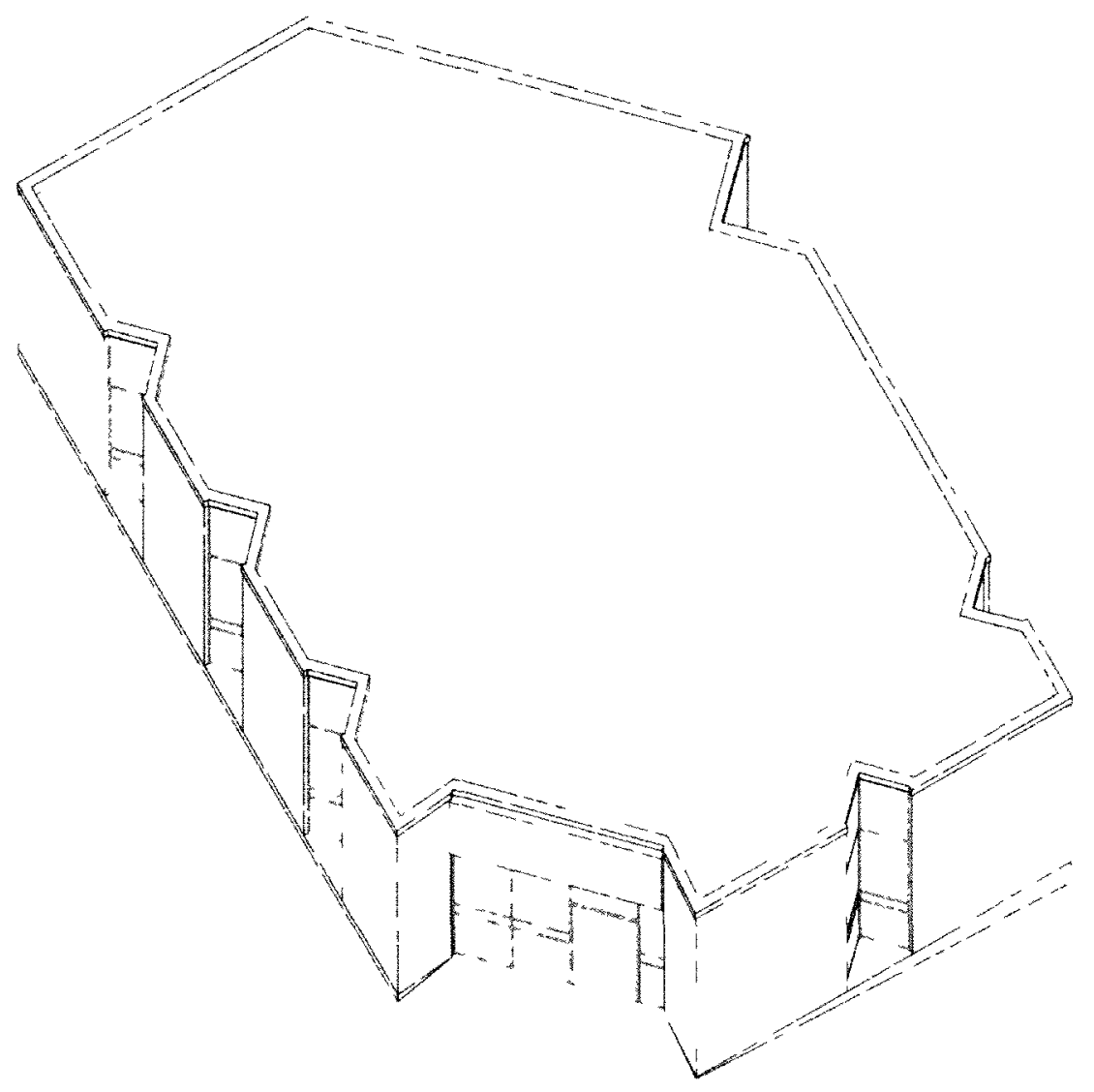

Figure 12: RBC Financial Group Branch \#1216 - Axonometric 

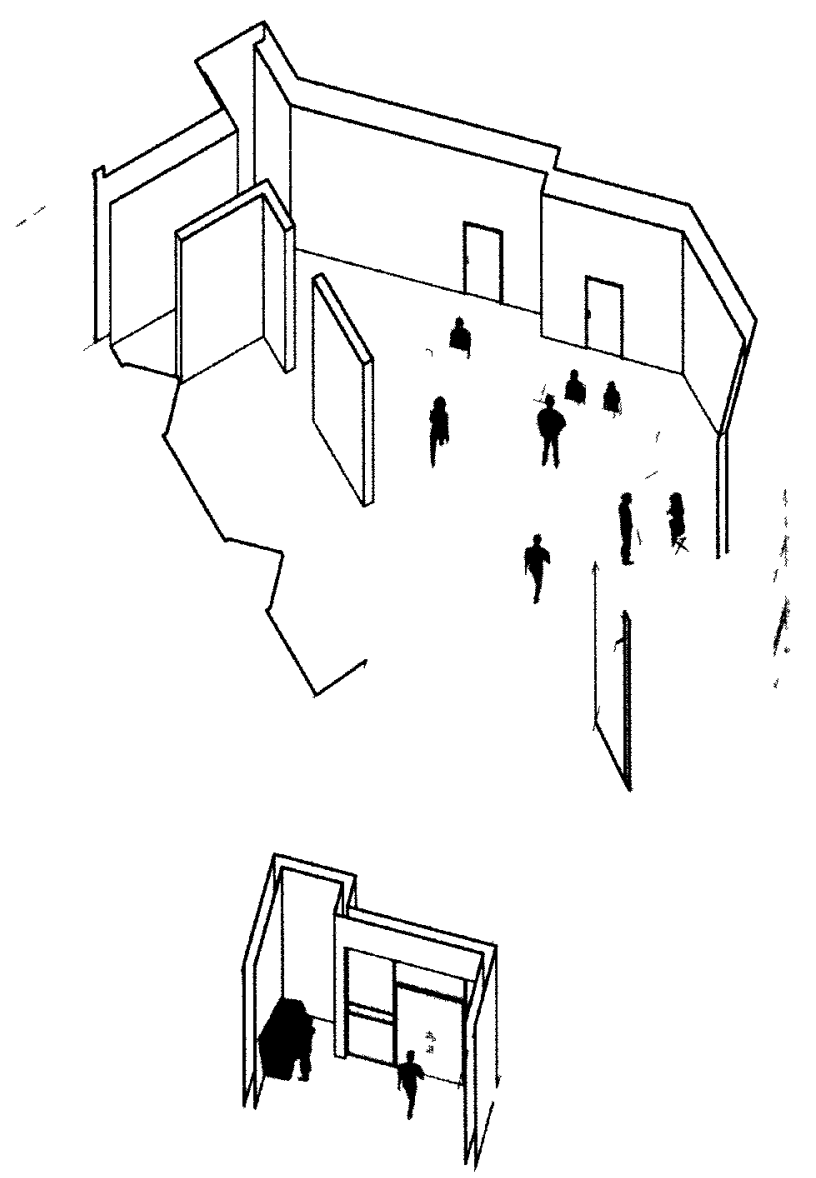

Figure 13: RBC Financial Group Branch \#1216 - Exploded Axonometric

Appendix $\mid 55$ 


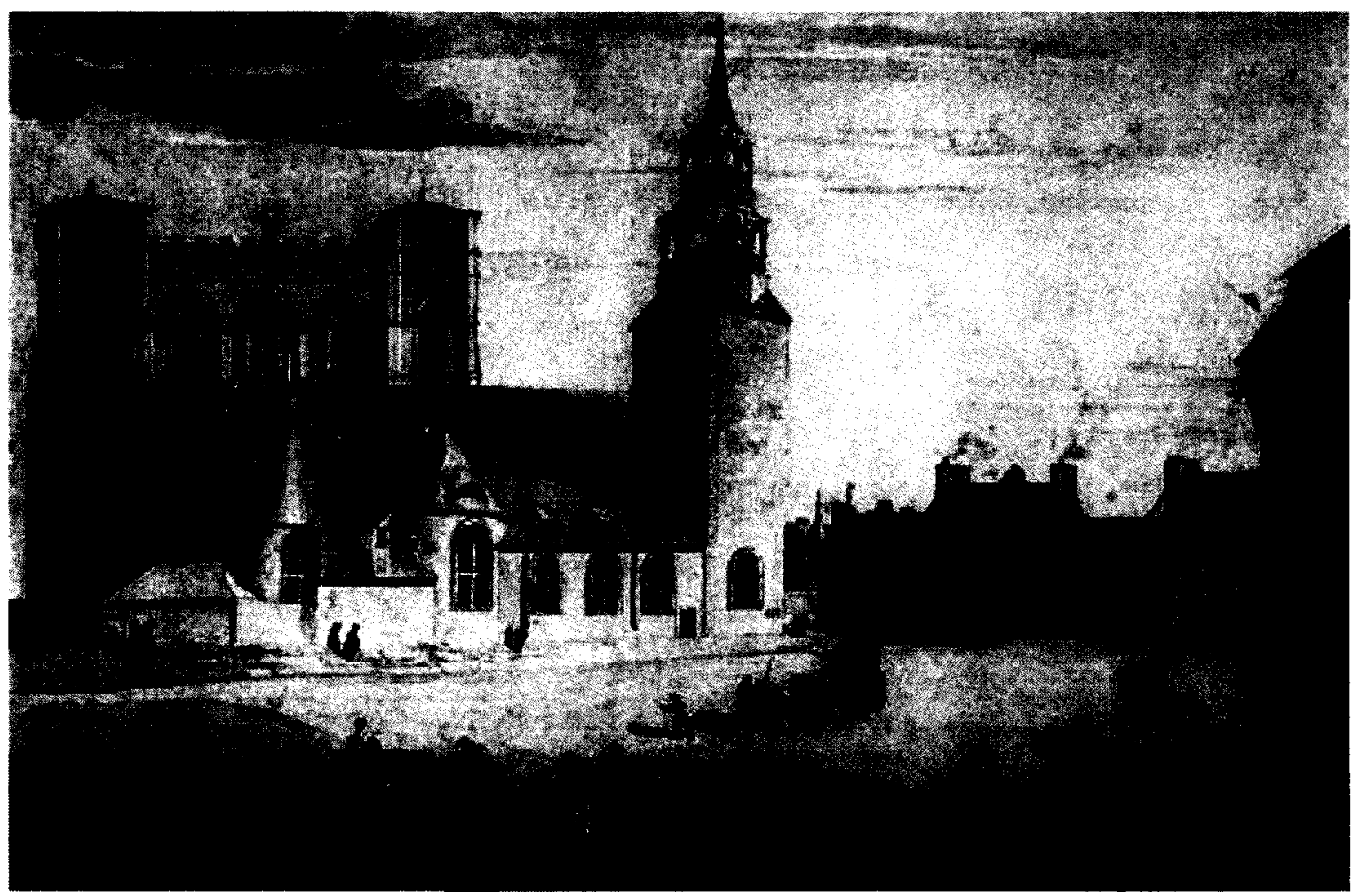

Figure 14: Place d'Armes, Montreal

Robert A. Sproule

1828

McCord Museum of Canadian History 


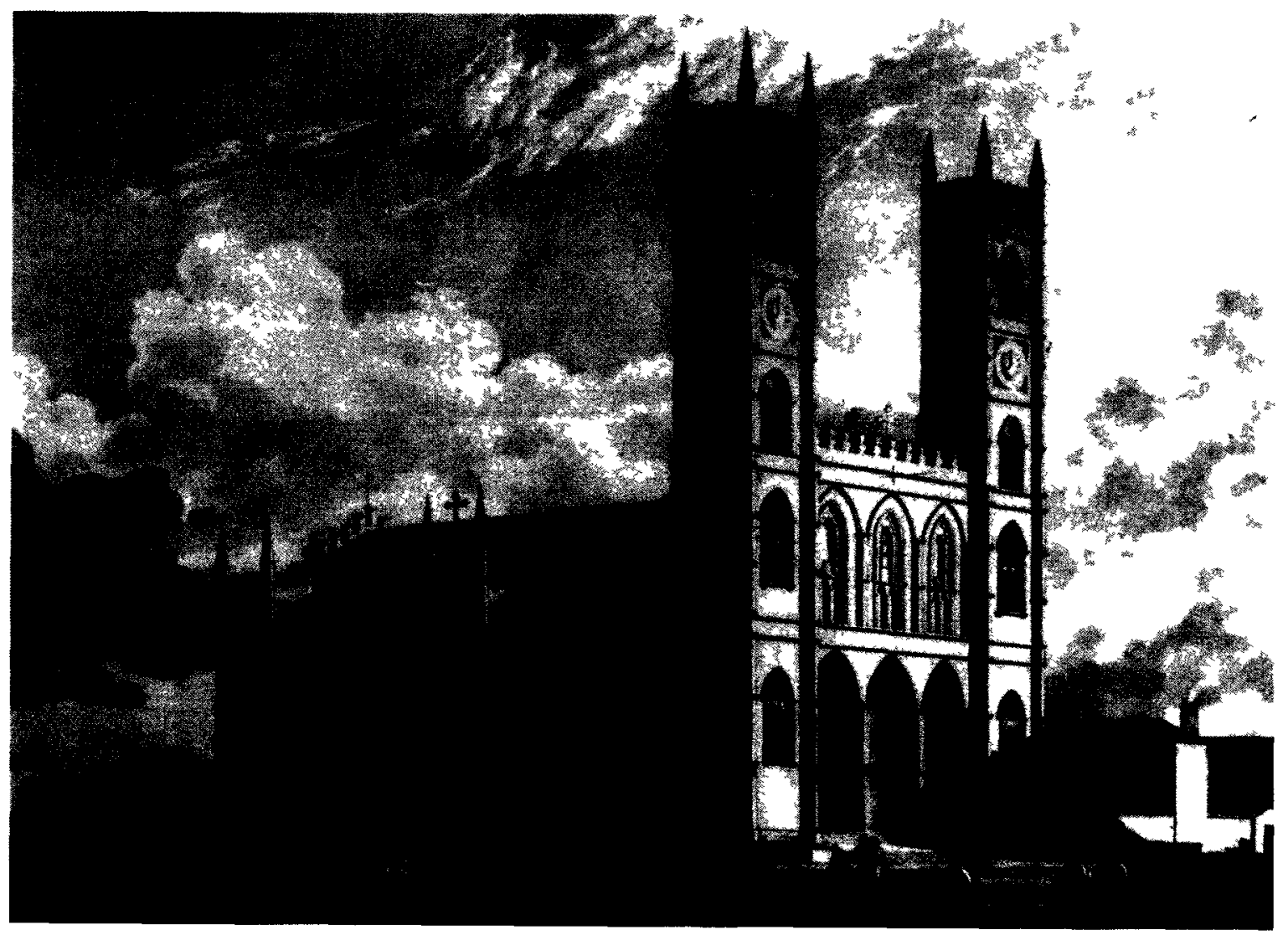

Figure 15: Exterıor of Notre Dame in 1834

The Church of Notre Dame in Montreal

Plate 25 


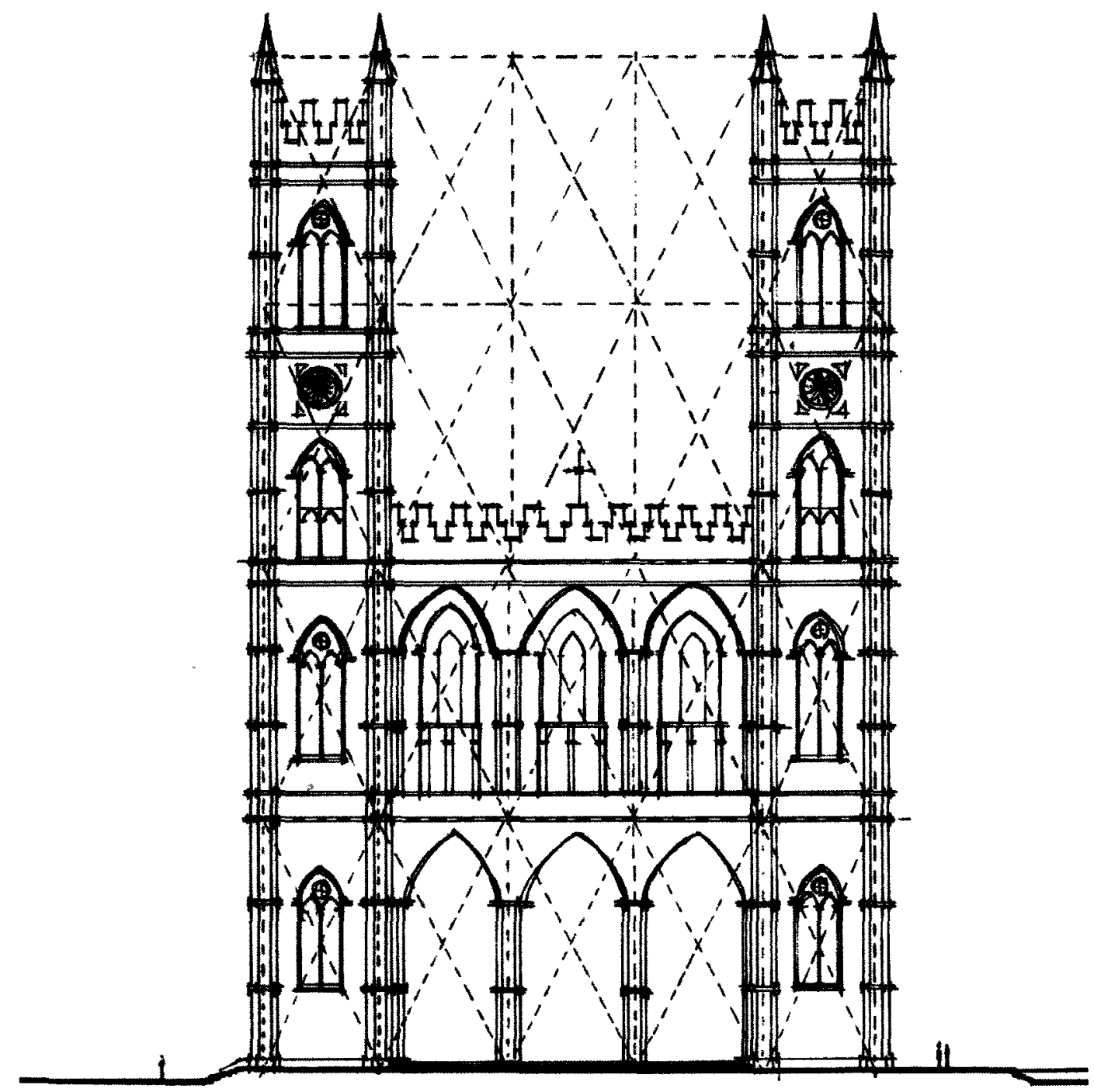

Figure 16: Modular System of the Façade of Notre Dame The Church of Notre Dame in Montreal Plate 24 


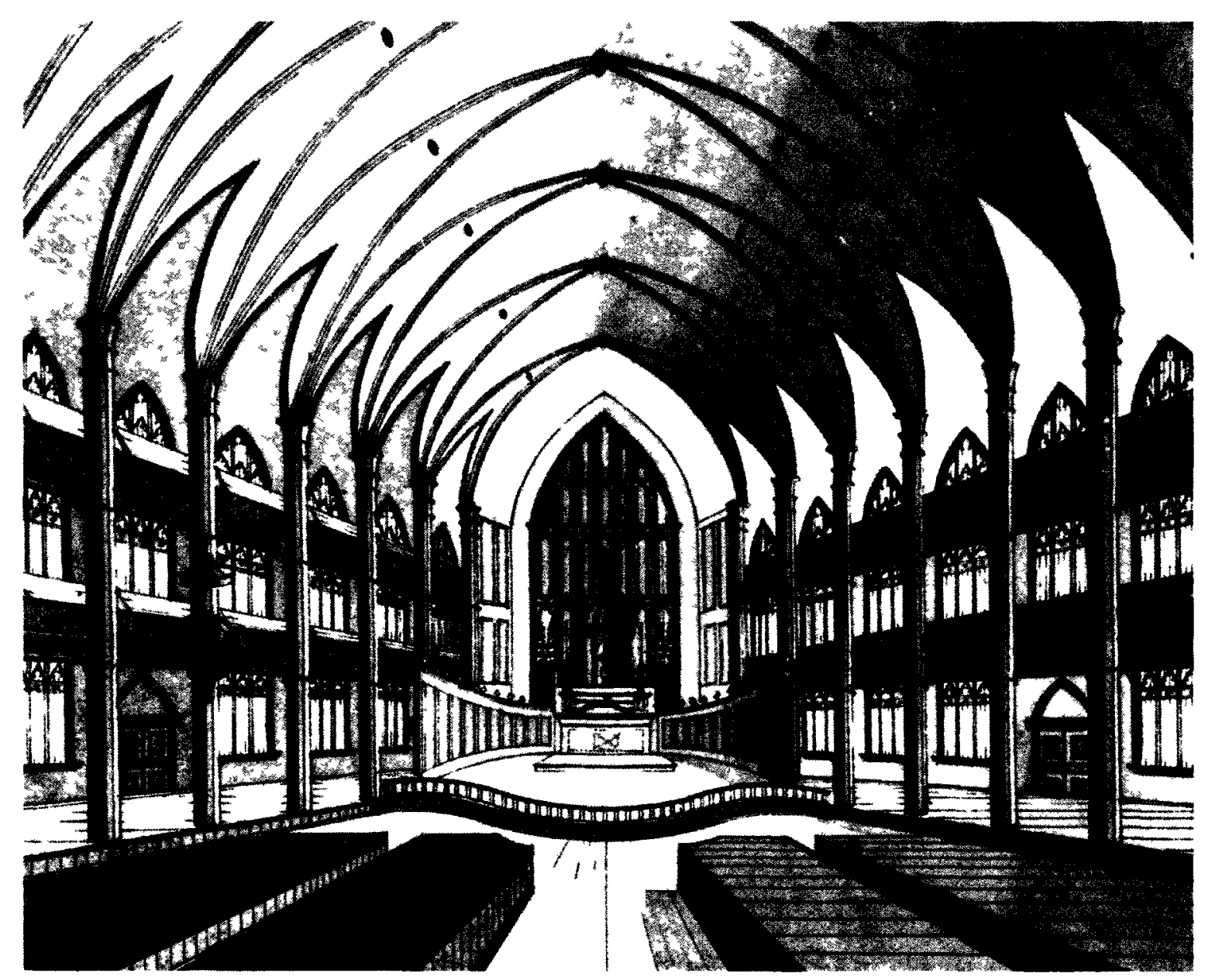

Figure 17: Interior View of Notre Dame

View of the sanctuary

The Church of Notre Dame in Montreal

Plate 14 


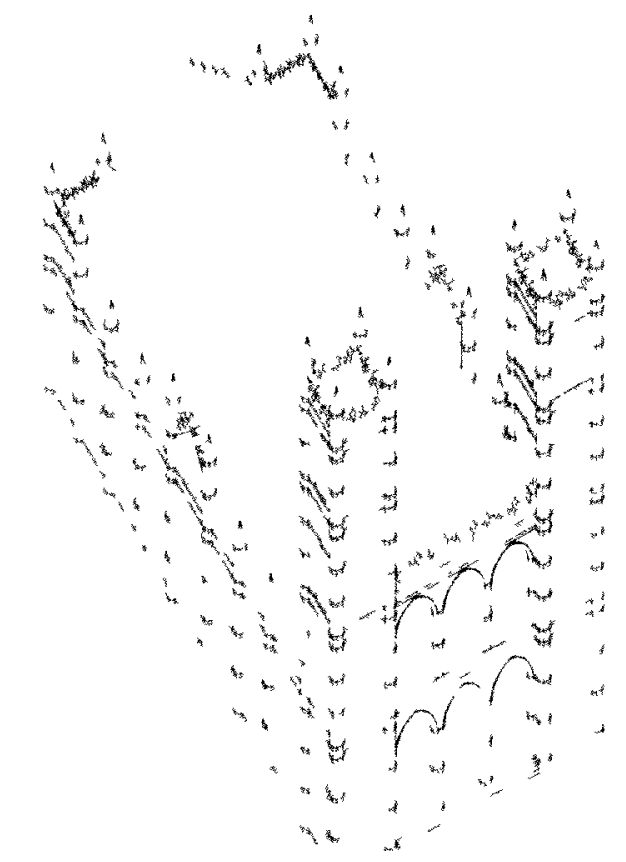

Figure 18: Notre Dame Basilica - Axonometric 


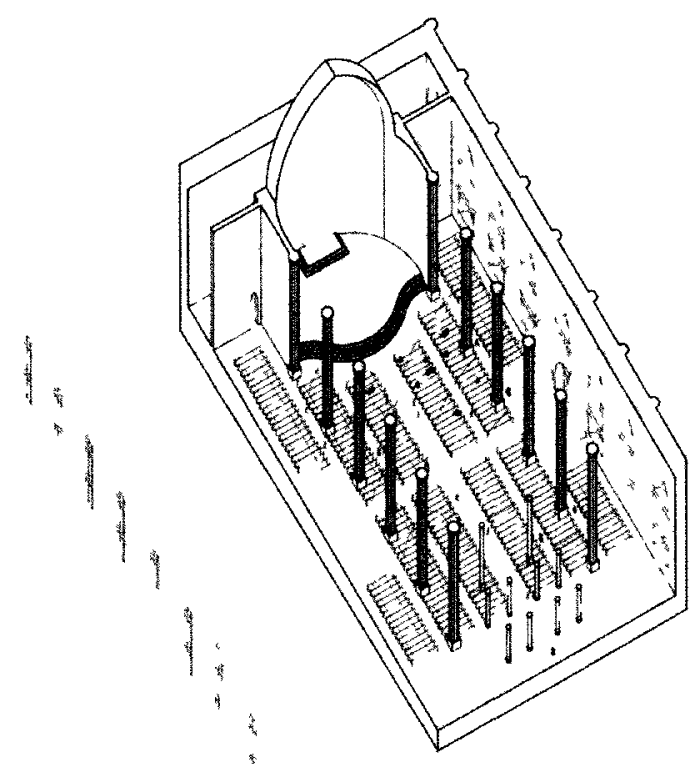

Figure 19: Notre Dame Basilica - Exploded Axonometric

Appendix $\mid 61$ 


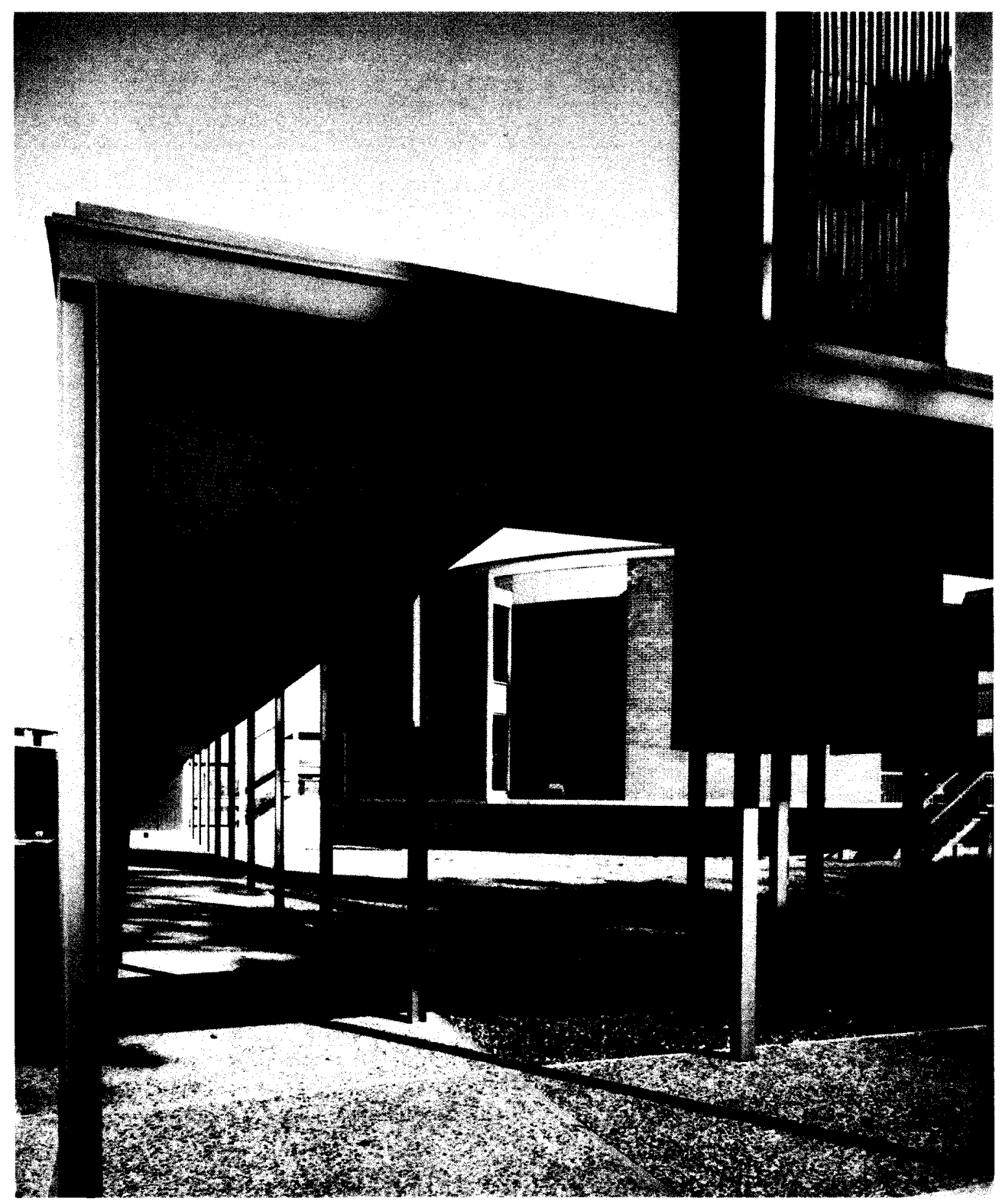

Figure 20: St. Basil's Roman Catholic Church View of the Entrance

Blessing of St. Basil's Church

Pg. 12 


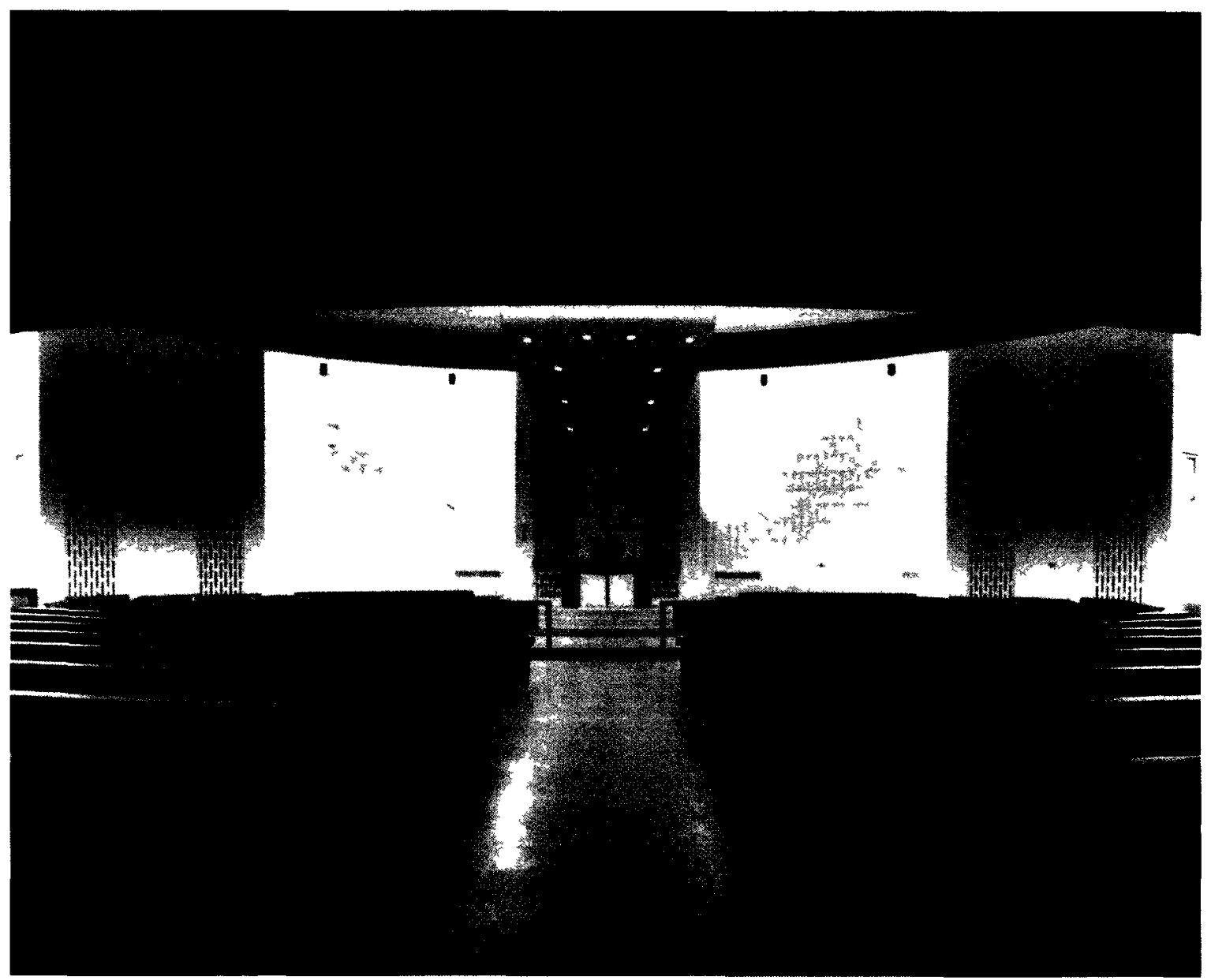

Figure 21: Interior View of St. Basil's Roman Catholic Church View of the sanctuary

"St Basıl's Roman Catholıc Church, Ottawa" $\mathrm{Pg} 50$ 


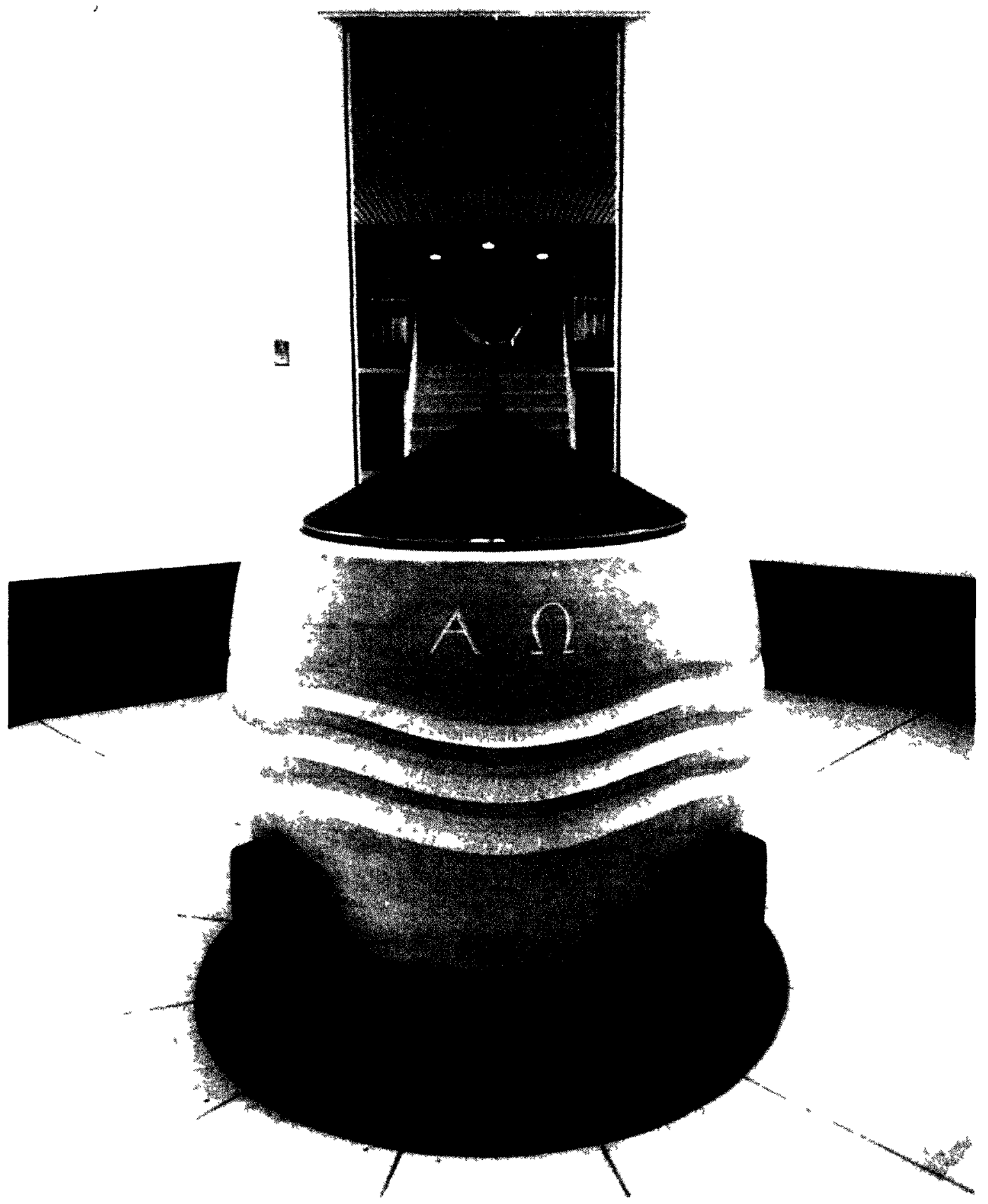

Figure 22: Interior View of St. Basil's Roman Catholic Church View from the baptistery toward the sanctuary Blessing of St Basl/'s Church

$\mathrm{Pg} 22$ 


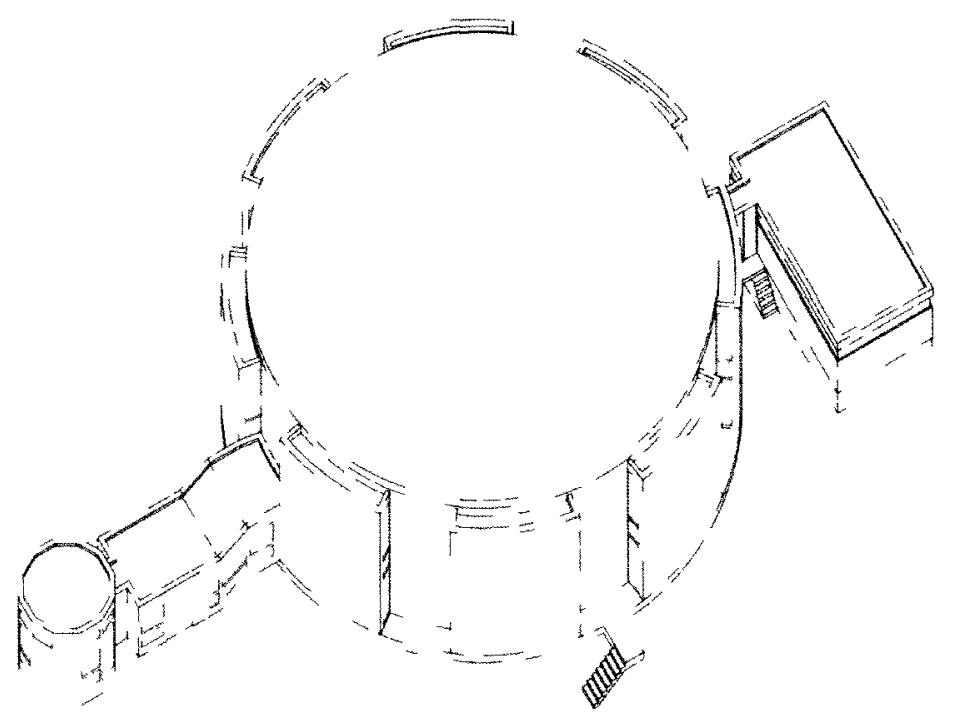

Figure 23: St. Basil's Roman Catholic Church - Axonometric 

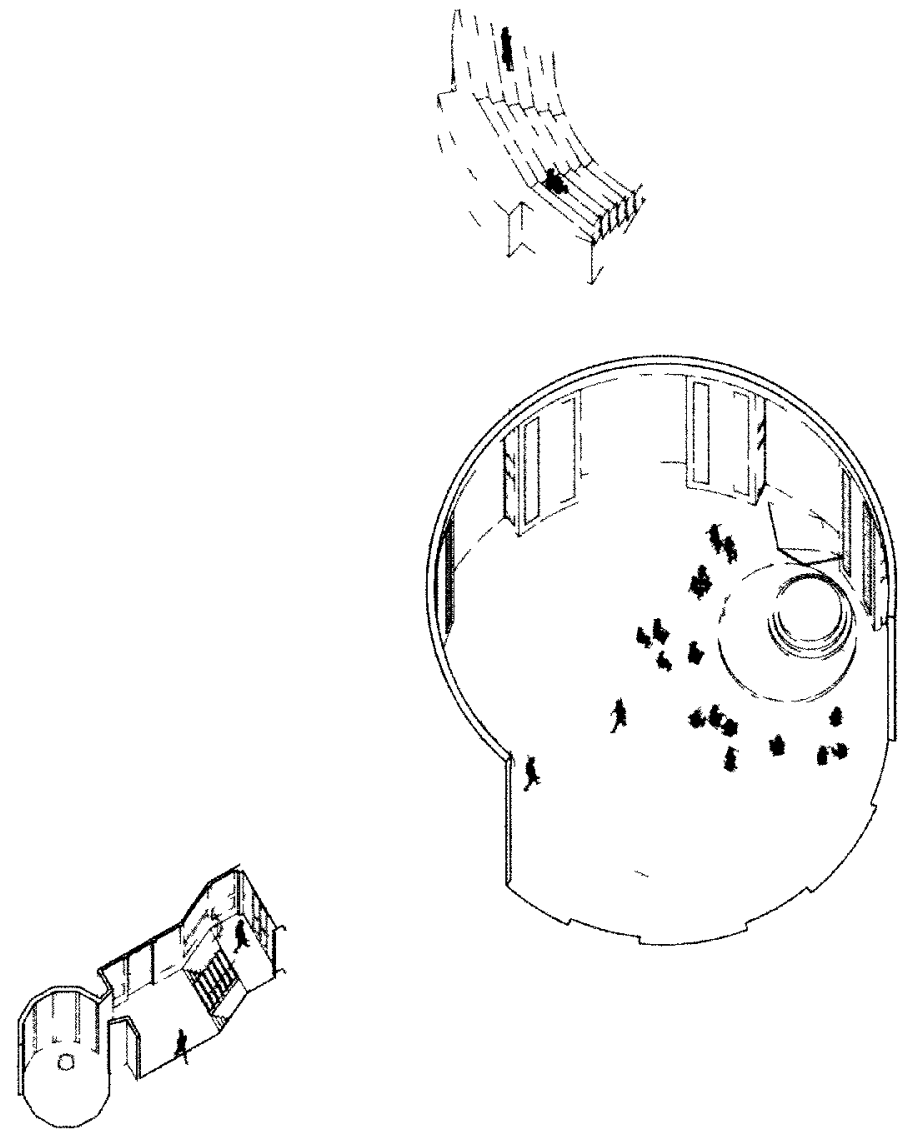

Figure 24: St. Basil's Roman Catholic Church - Exploded Axonometric 


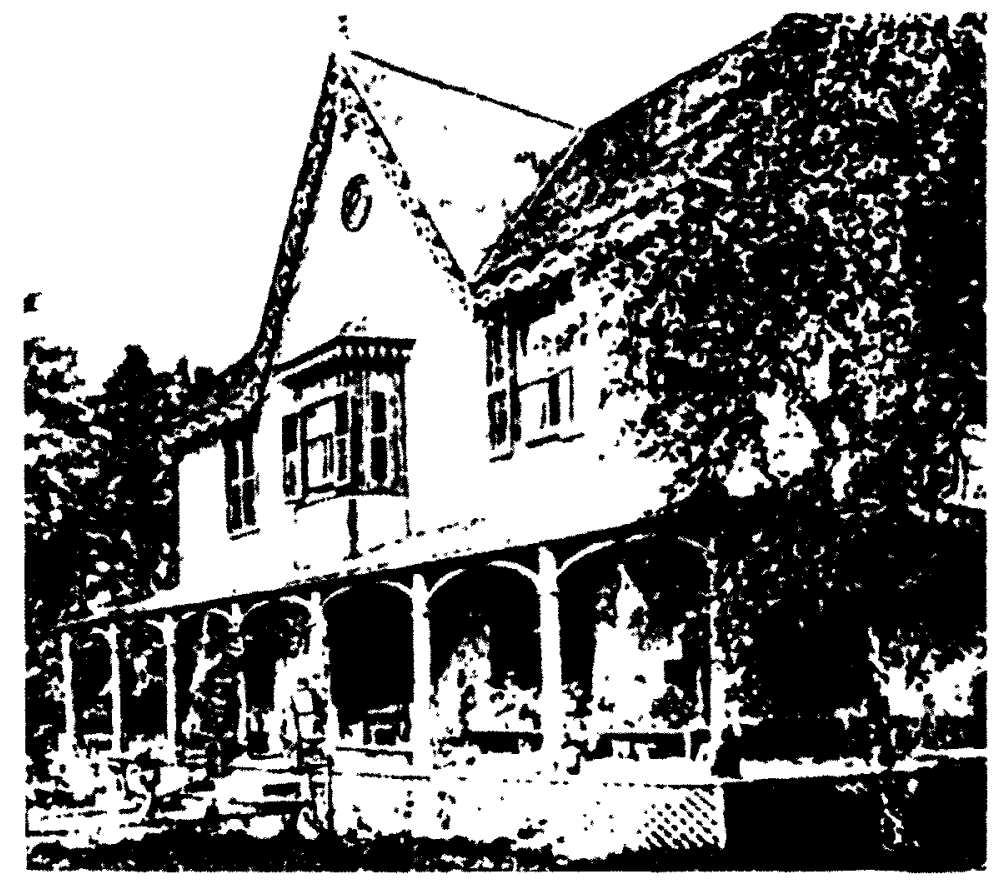

Figure 25: New Orpington Lodge

Late 1800's

A History of the Queen of the Most Holy Rosary Parish 


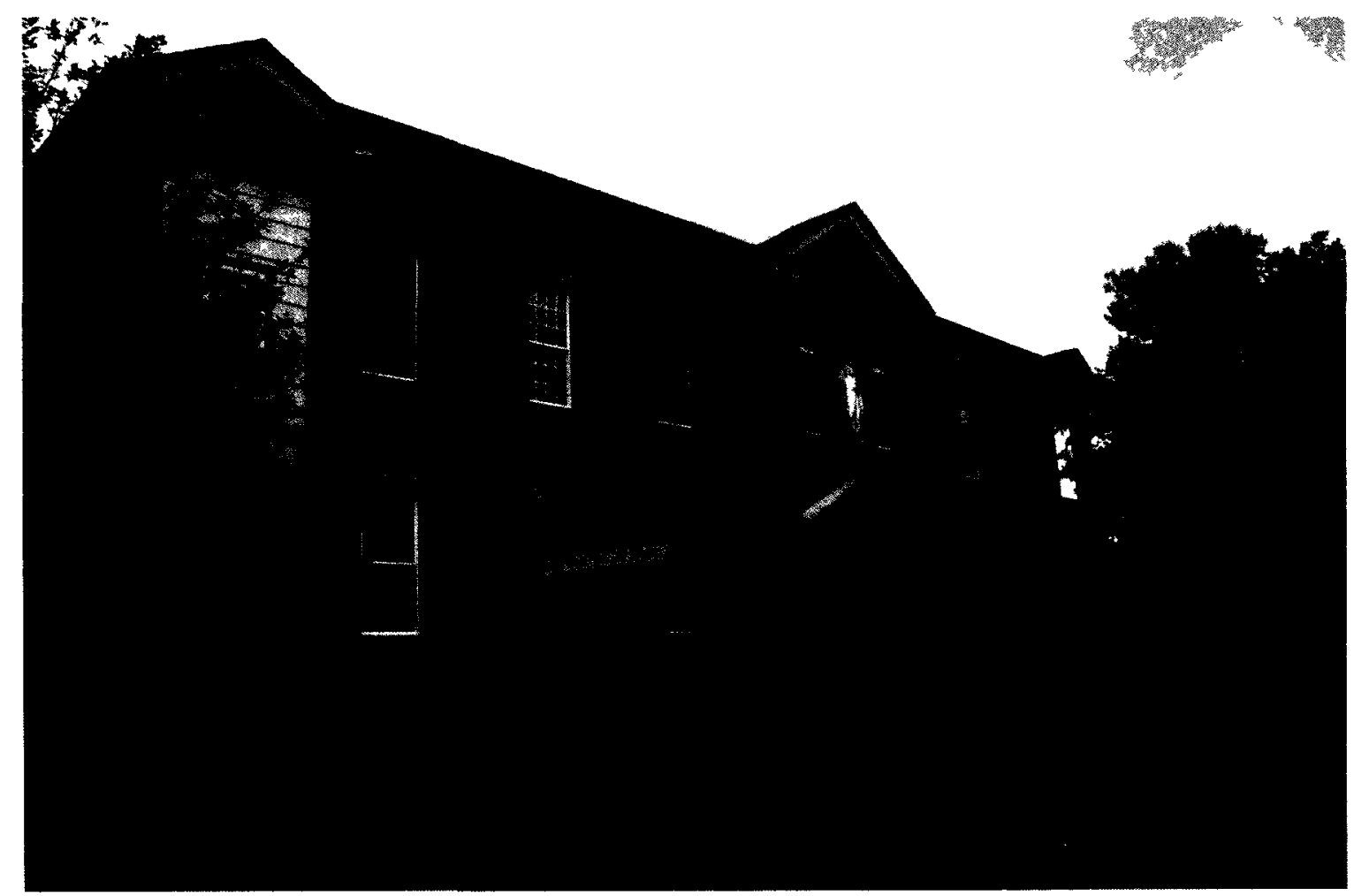

Figure 26: Queen of the Most Holy Rosary Roman Catholic Church View from Wellıngton Street West 


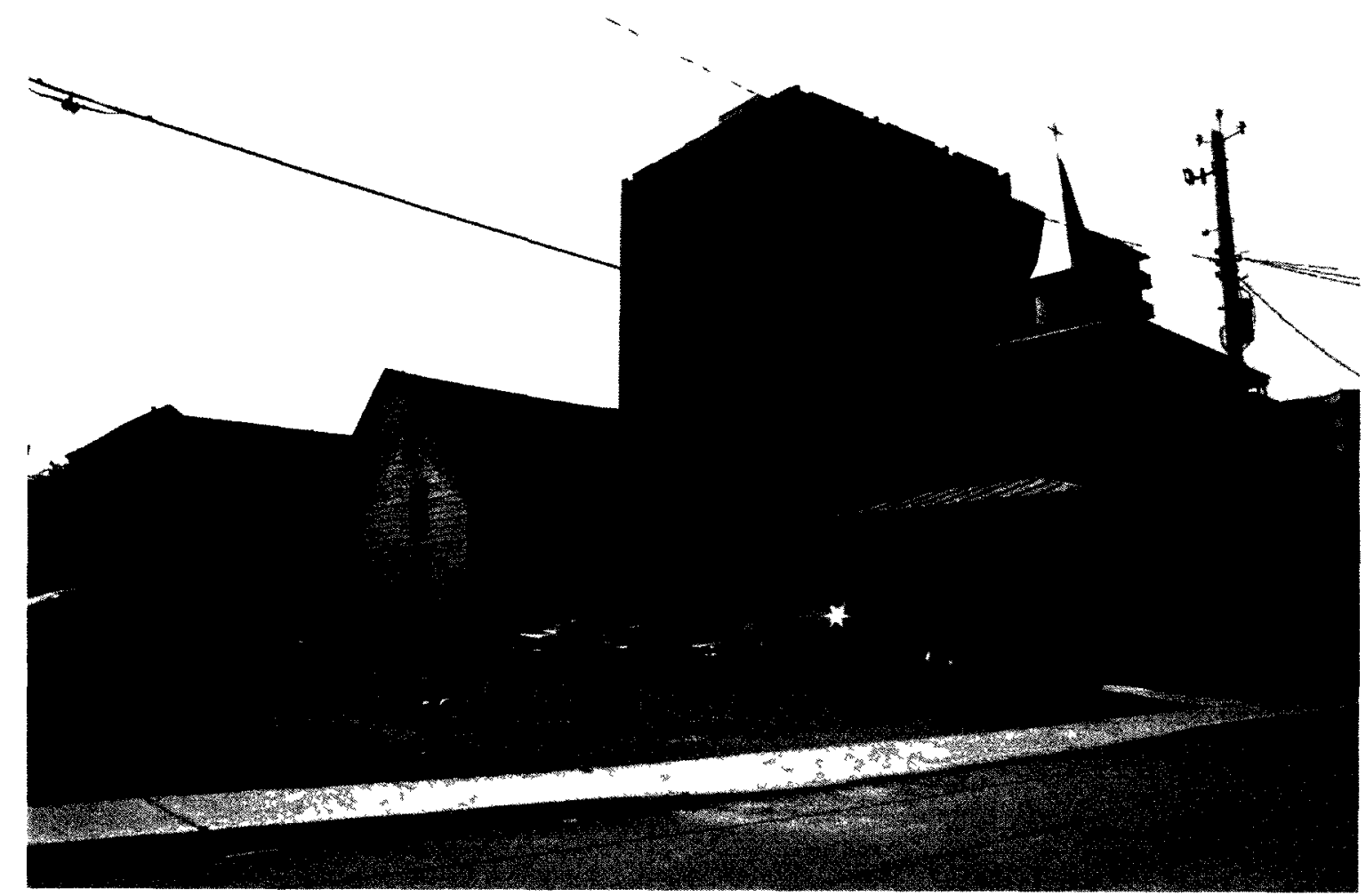

Figure 27: Queen of the Most Holy Rosary Roman Catholic Church View from Grant Street 


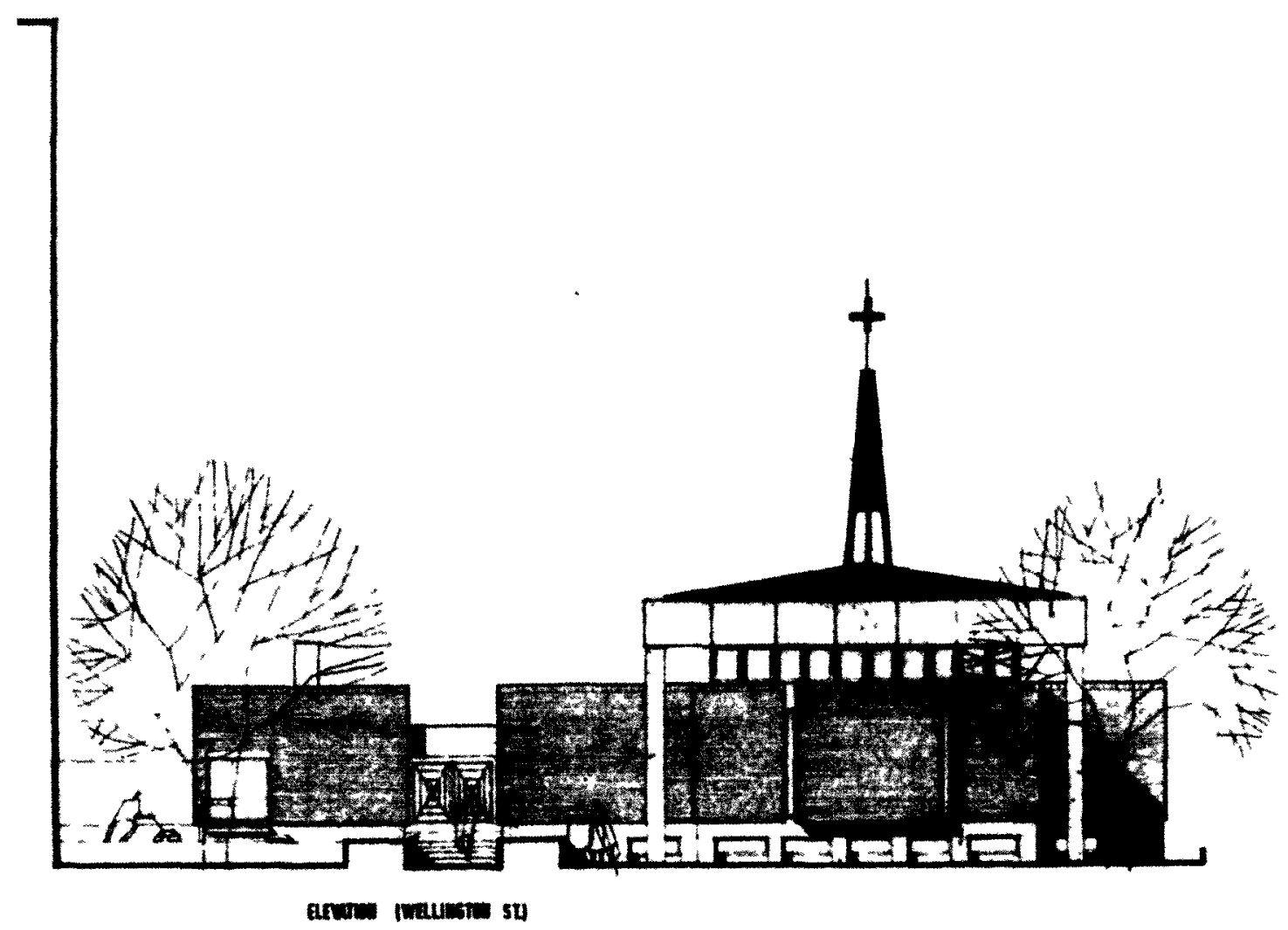

Figure 28: Queen of the Most Holy Rosary Roman Catholic Church - Proposed Building Murray and Murray Architects 


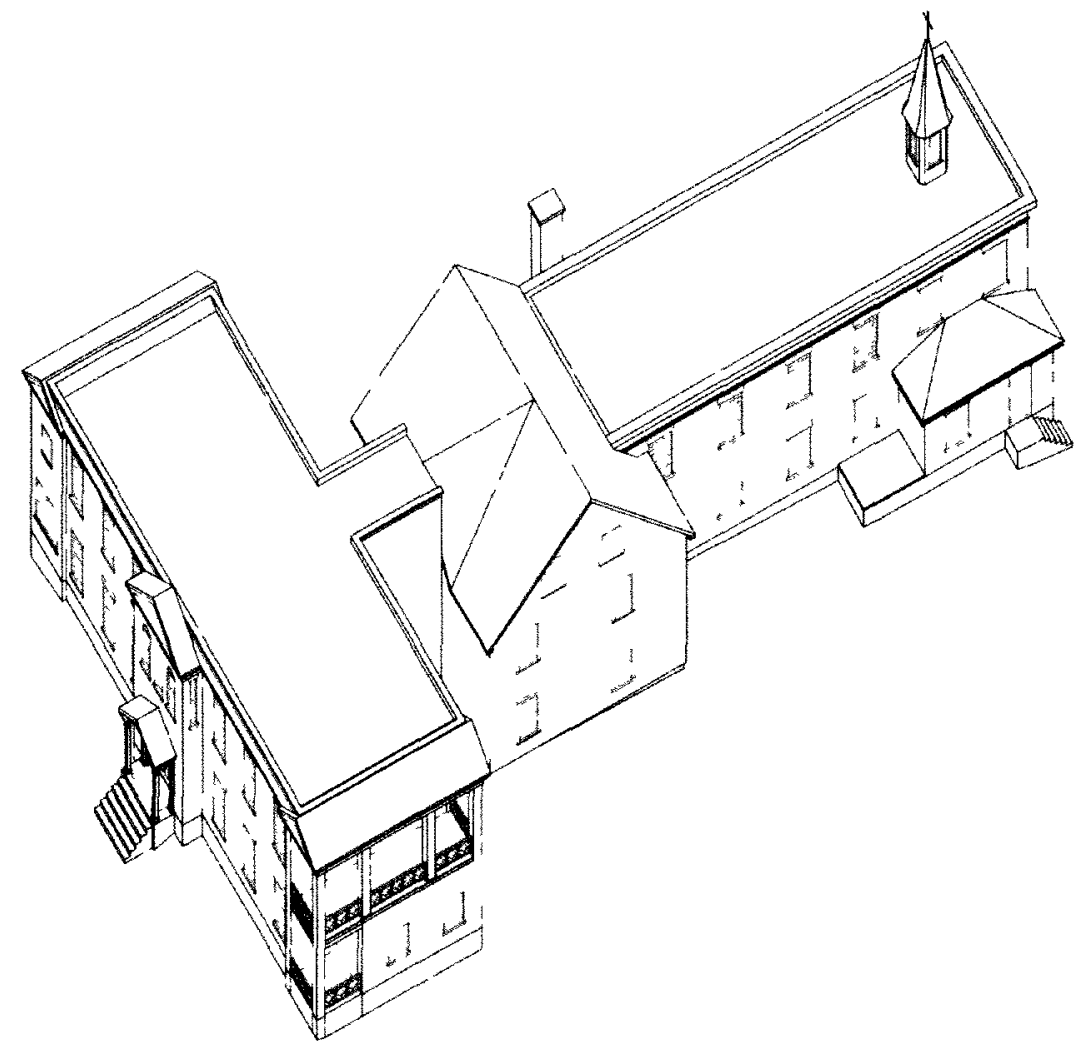

Figure 29: Queen of the Most Holy Rosary Roman Catholic Church - Axonometric 


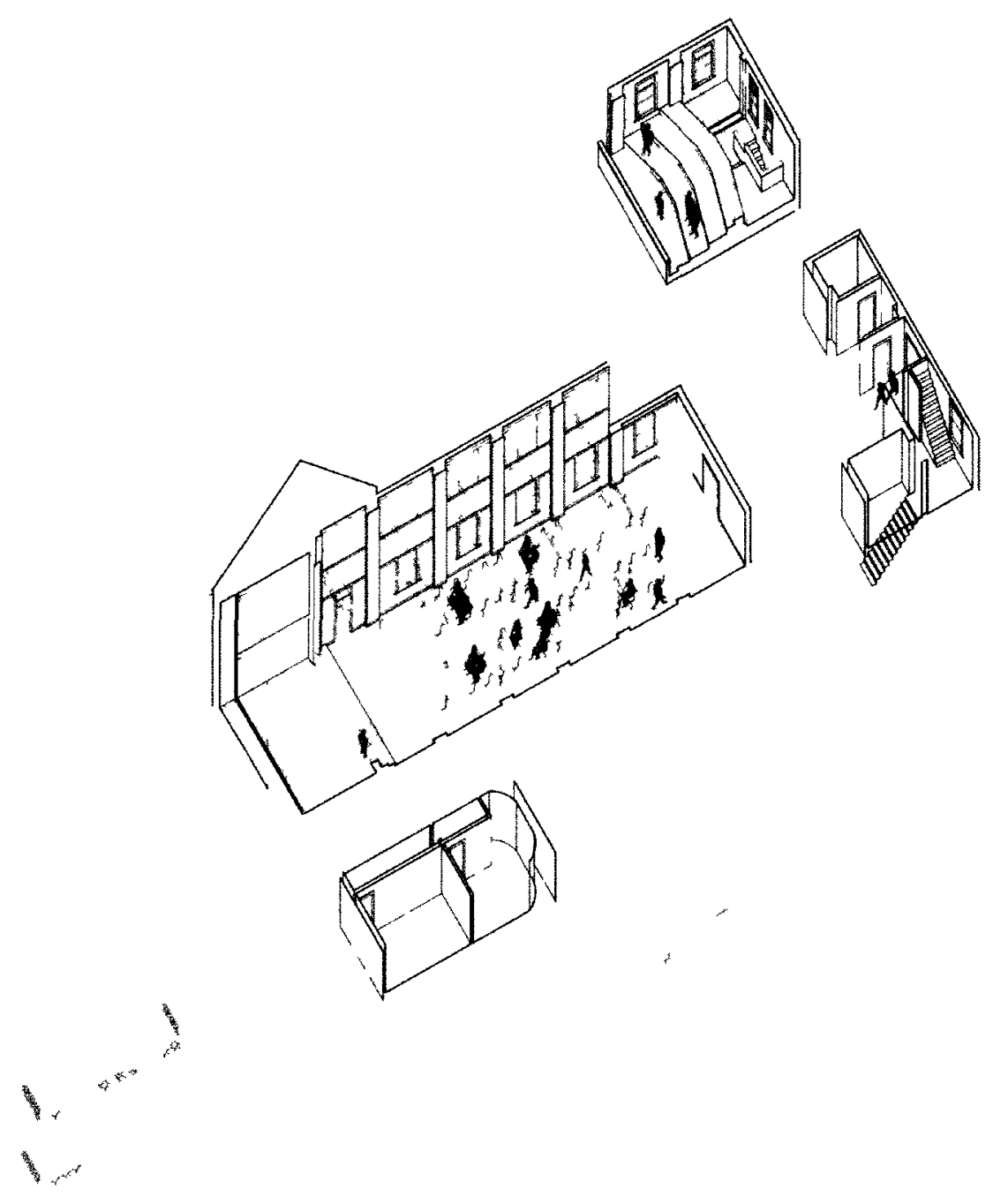

Figure 30: Queen of the Most Holy Rosary Roman Catholic Church - Exploded Axonometric 


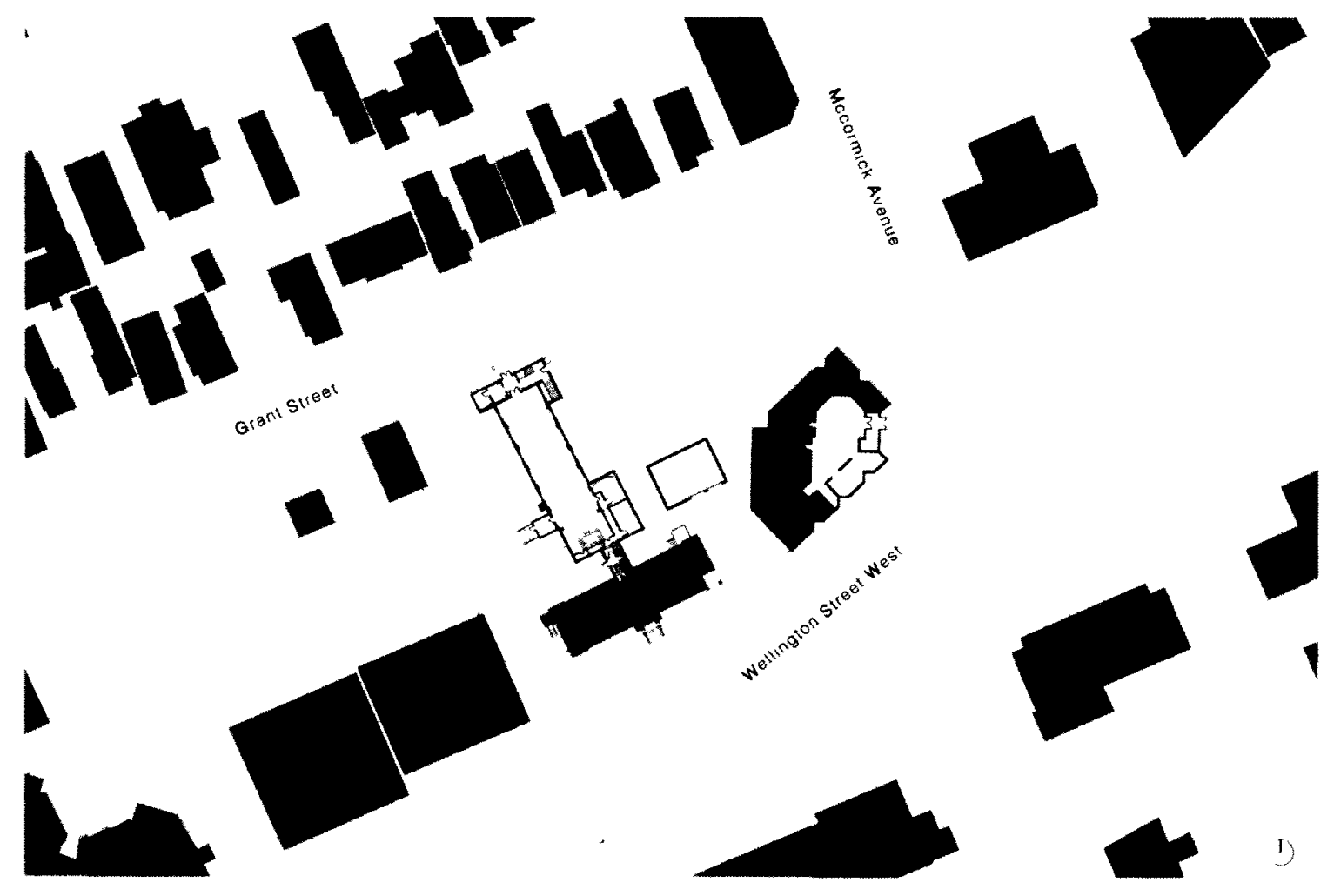

Figure 31: Existing Site Plan 


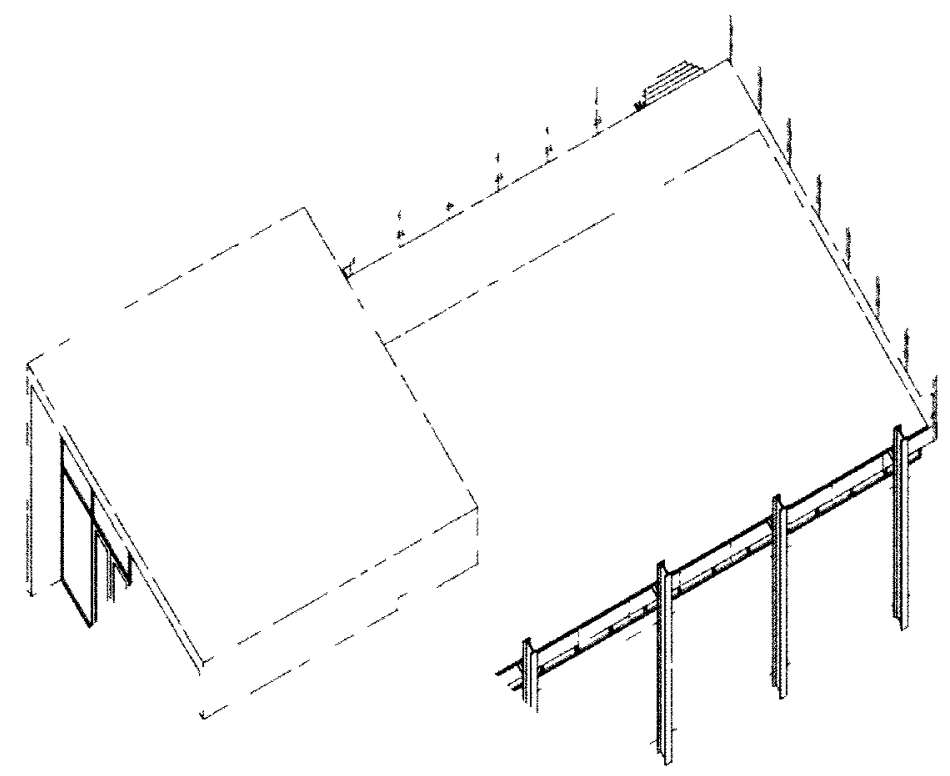

Figure 32: RBC Financial Group Branch \#1216 - Proposed Addition 

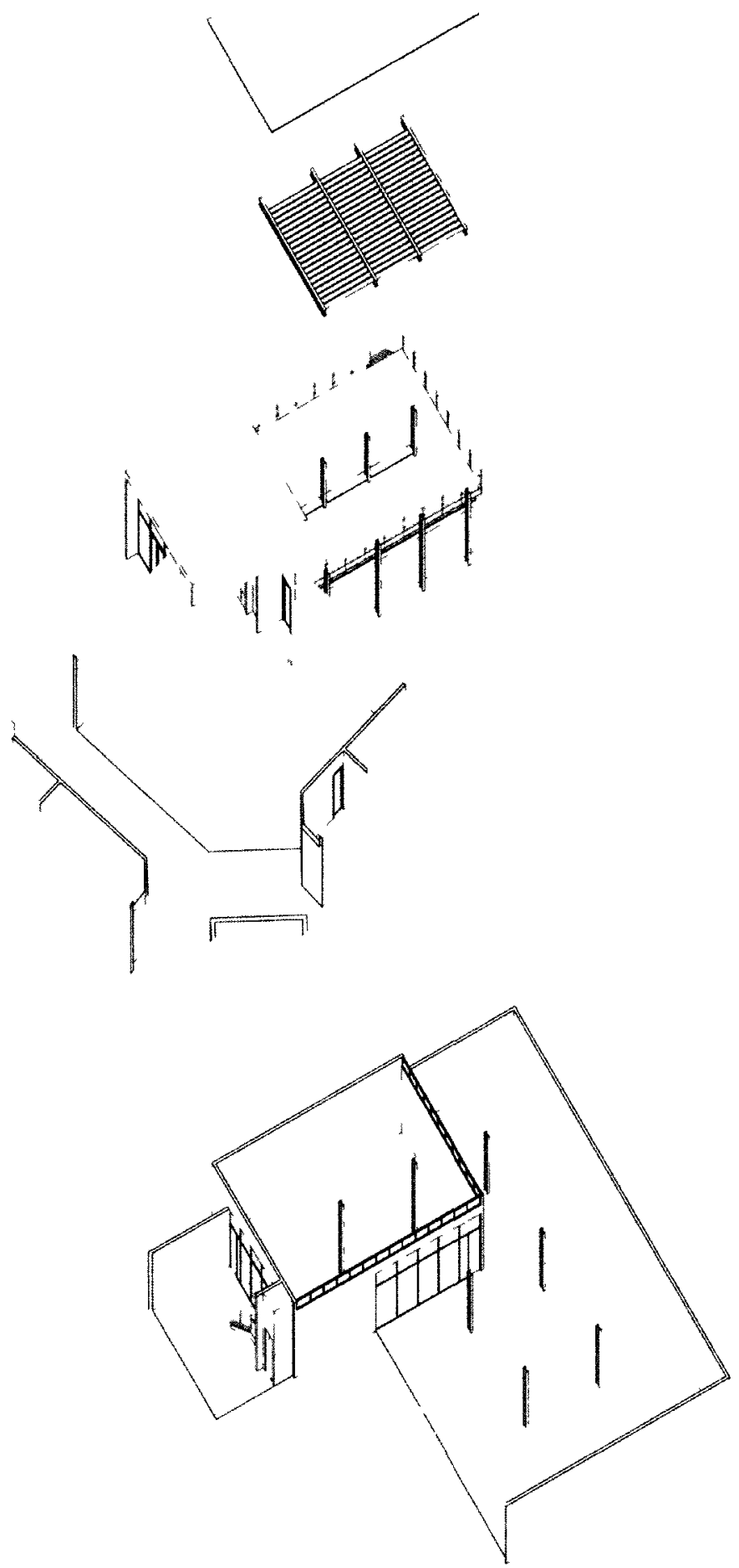

Figure 33: RBC Financial Group Branch \#1216 - Proposed Addition

Exploded Axonometric 


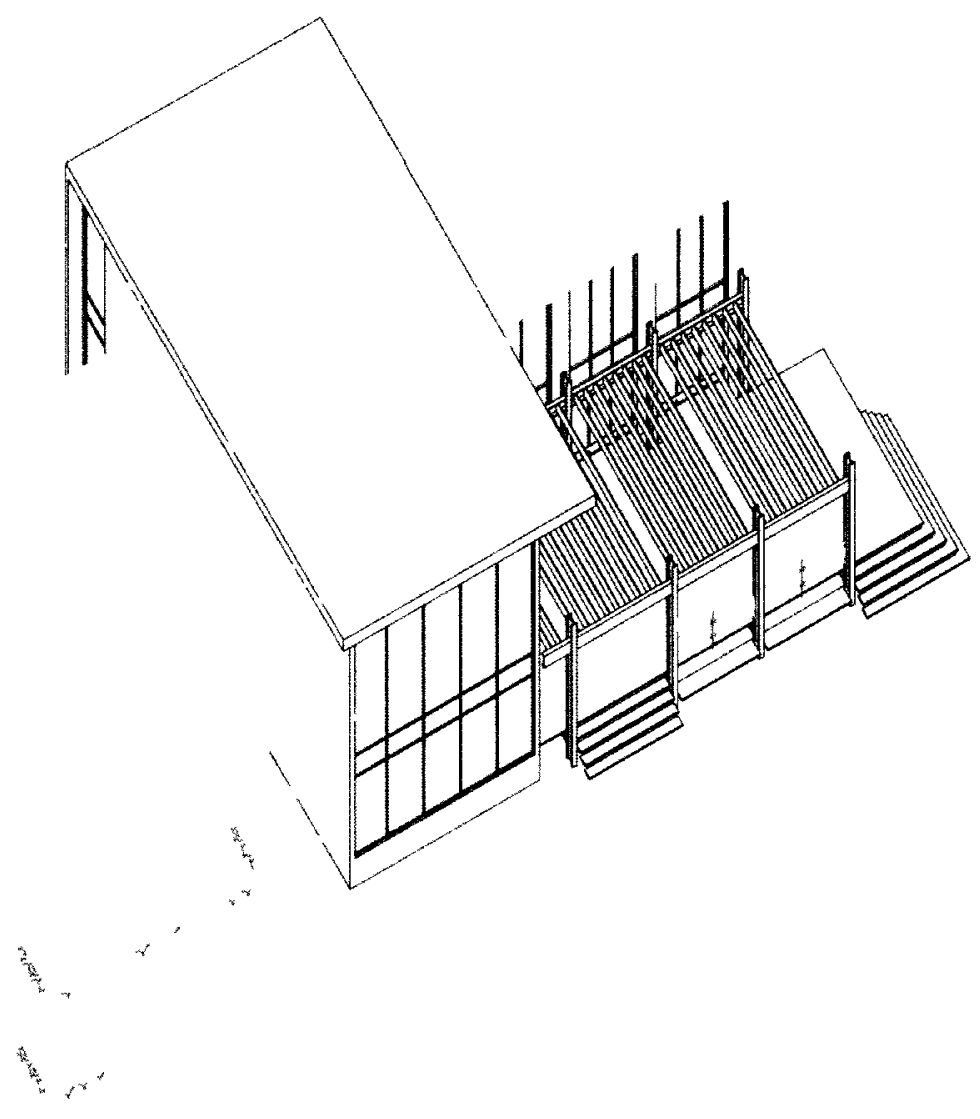

Figure 34: Queen of the Most Holy Rosary Roman Catholic Church - Proposed Addition 

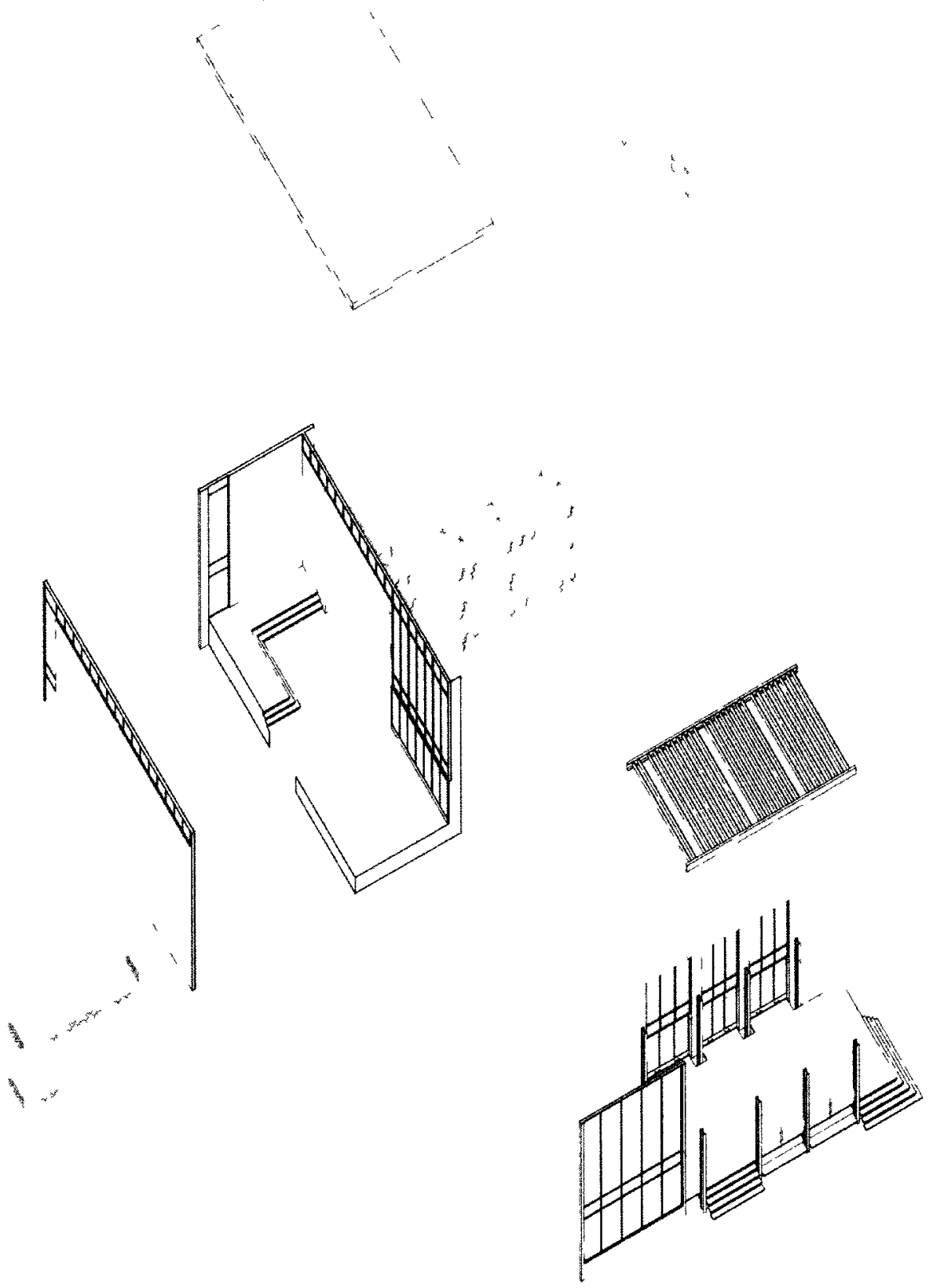

Figure 35: Queen of the Most Holy Rosary Roman Catholic Church - Proposed Addition Exploded Axonometric 


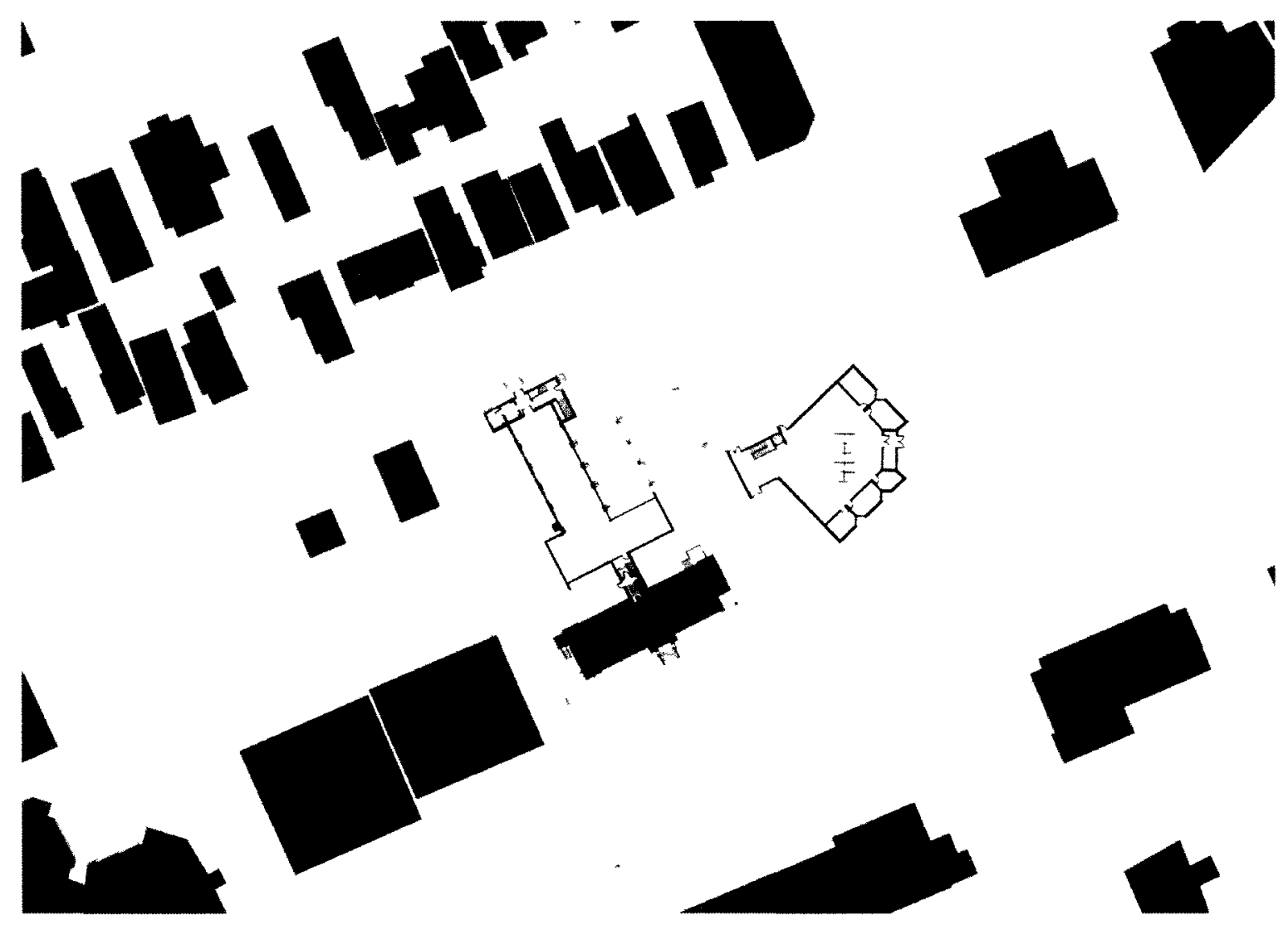

Figure 36: Proposed Project - Site Plan 

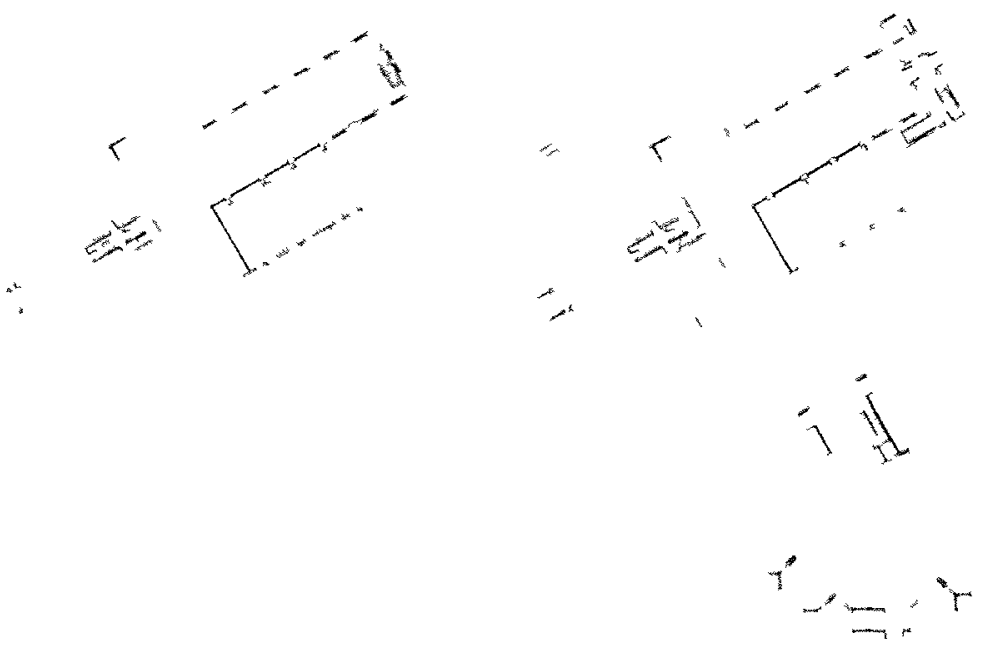

Figure 37: Proposed Project - Floor Plans 


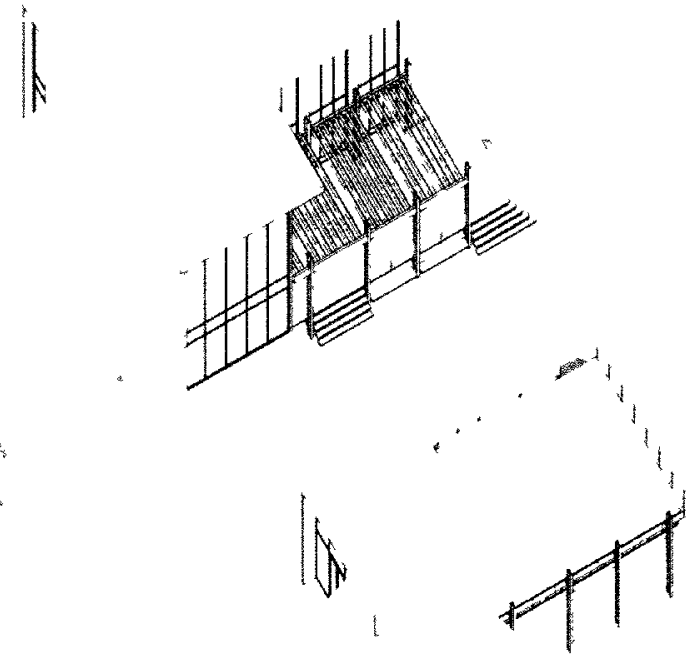

Figure 38: Proposed Project - Axonometric 

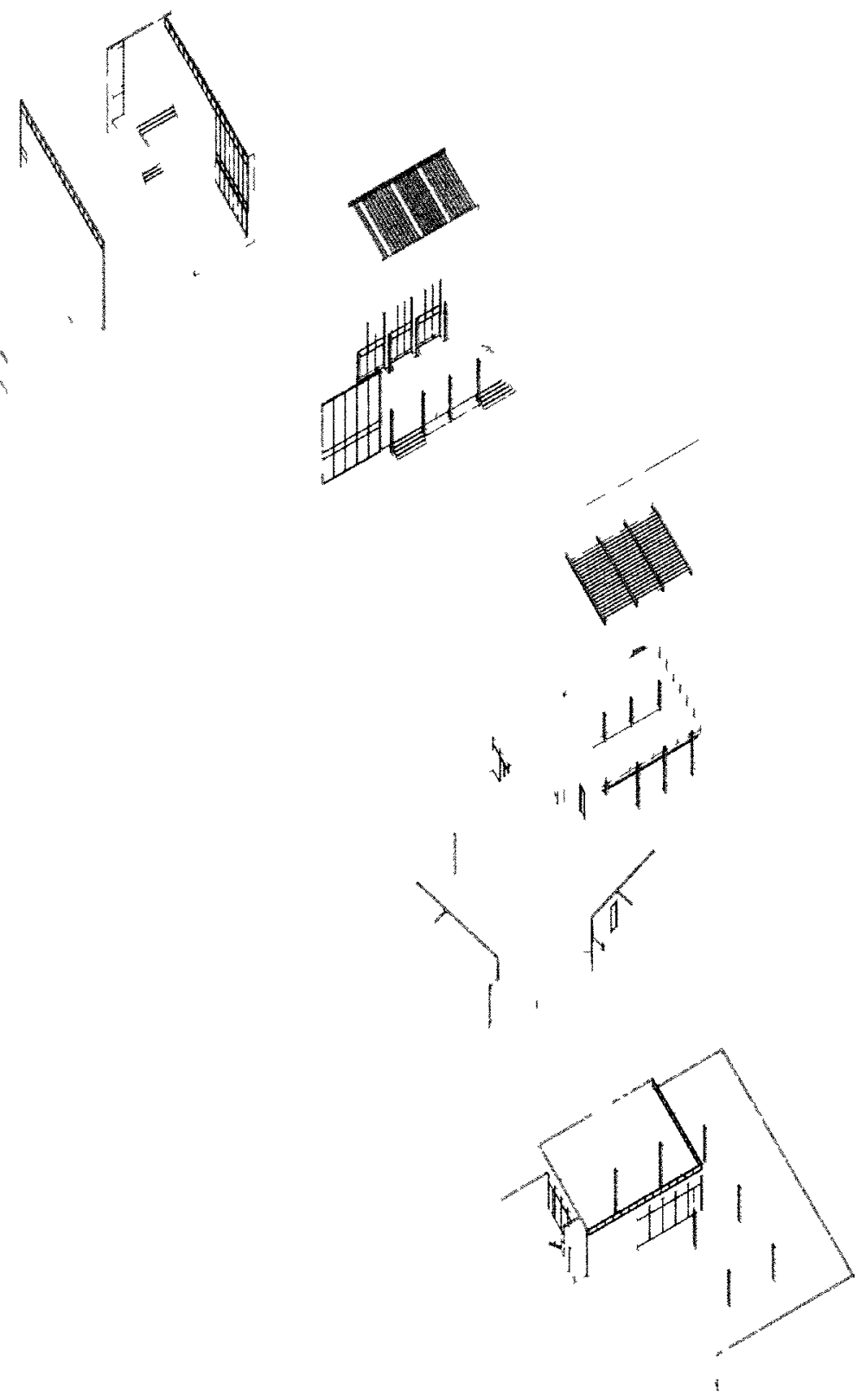

Figure 39: Proposed Project - Exploded Axonometric 


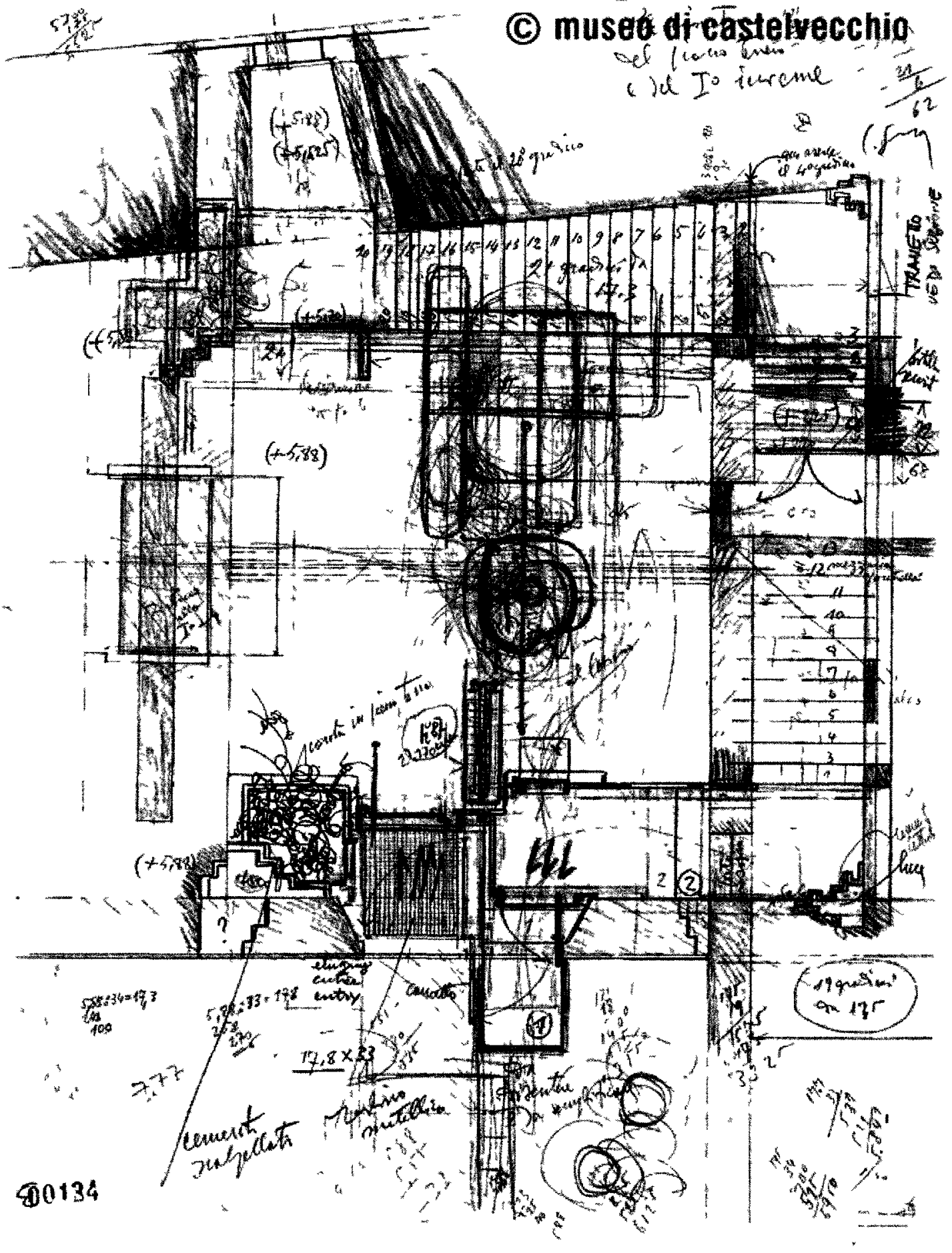

Figure 40: Castelvecchio - Plan of Entry

Carlo Scarpa

Museo Civıco dı Castelvecchıo 

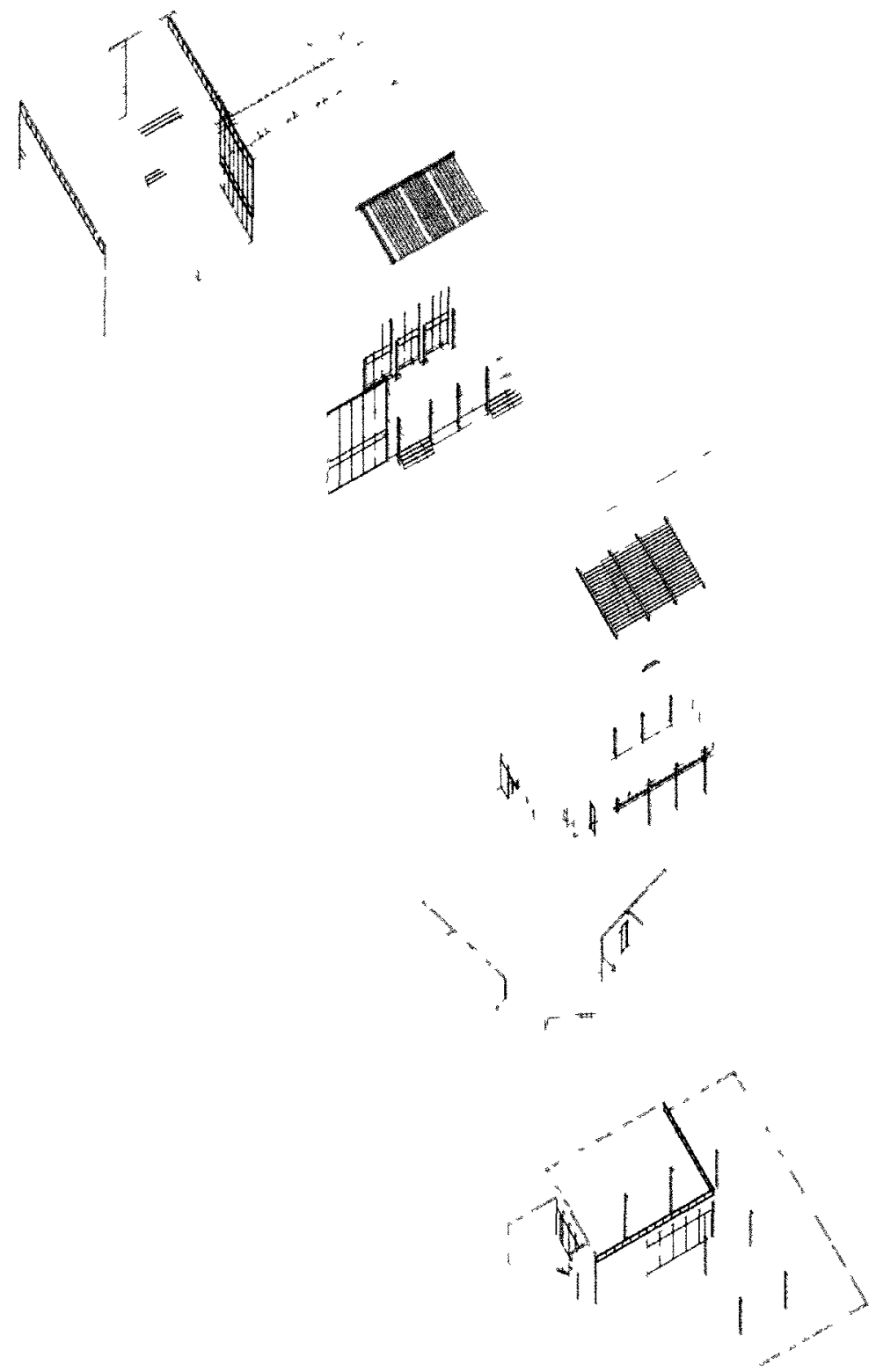

Figure 41: Proposed Project - Exploded Axonometric 


\section{Works Cited}

A History of Queen of the Most Holy Rosary Parish. Ottawa, Ontario. Unpublished, 1987.

Blessing of St. Basil's Church. Unpublished, 1961.

Brown, Jean M., Naomi Mindlin and Charles Humphrey Woodford. The Vision of Modern Dance: In the Words of Its Creators. Hightstown: Princeton Book Company, 1998.

"Carlo Scarpa - Digital Archive". 17 September 2011

$<$ http://www.archiviocarloscarpa.it/index.php?lingua=e>.

Dean, Stephen, ed. Celebration: The Liturgy Handbook. New York: Geoffrey Chapman, 1993.

"Dei Verbum". 18 November 1965. 24 July 2011

$<$ http://www.vatican.va/archive/hist_councils/ii_vatican_council/documents/vatii_const_19651118_dei-verbum_en.html>.

"Gaudium Et Spes". 7 December 1965. 24 July 2011

$<$ http://www.vatican.va/archive/hist_councils/ii_vatican_council/documents/vatii_cons_19651207_gaudium-et-spes_en.html>.

"History of Hintonburg." Hintonburg Community Association. 11012011 $<$ http://www.hintonburg.com/history.html>.

Humphry, Doris. The Art of Making Dances. Hightstown: Princeton Book Company, 1991.

"Lumen Gentium". 21 November 1964. 24 July 2011

$<$ http://www.vatican.va/archive/hist_councils/ii_vatican_council/documents/vatii_const_19641121_lumen-gentium_en.html>. 
McEvoy, Frederick J. "These Treasures of the Church of God: Catholic Child Immigration to Canada." 1999. CCHA, Historical Studies. 11012011 <http://www.umanitoba.ca/colleges/st_pauls/ccha/Back\%20lssues/CCHA1999/ McEvoy.htm>.

Money Matters: A Critical Look at Bank Architecture. New York: McGraw Hill Publishing Company, 1990.

Nolin-Raynauld, Michelle. The Bank of Montreal Building on Place D'Armes: 1845-1901. Montreal: Varia Press, 1999.

"Sacrosanctum Concilium". 4 December 1963. 24 July 2011 <http://www.vatican.va/archive/hist_councils/ii_vatican_council/documents/vatii_const_19631204_sacrosanctum-concilium_en.html>.

Schulze, Franz, ed. The Mies van der Rohe Archive. Vol. 19. New York: Garland Publishing, Inc., 1992.

"St. Basil's Church, Ottawa, Ontario." Canadian Catholic Institutions 3.6 (1961): 27-30.

"St. Basil's Roman Catholic Church." Royal Architectural Institute of Canada Journal 38.12 (1961): 48-52.

Toker, Franklin. The Church of Notre-Dame in Montreal. Montreal: McGill-Queen University Press, 1970.

Wentzel, F. "Toronto Without the Tower". 1 August 2009. 15 August 2011 <http://citynoise.org/article/9688>. 